First publ. in: Molecular Phylogenetics and Evolution 43 (2007), pp. 567-582

\title{
Revealing cryptic diversity using molecular phylogenetics and phylogeography in frogs of the Scinax ruber and Rhinella margaritifera species groups
}

\author{
Antoine Fouquet ${ }^{\text {a,f,* }}$, Miguel Vences ${ }^{\mathrm{b}}$, Marie-Dominique Salducci ${ }^{\mathrm{a}}$, \\ Axel Meyer ${ }^{\mathrm{c}}$, Christian Marty ${ }^{\mathrm{d}}$, Michel Blanc ${ }^{\mathrm{e}}$, André Gilles ${ }^{\mathrm{a}}$ \\ ${ }^{\text {a }}$ EA 3781 EGEE Evolution Genome Environment, Université de Provence, Centre St. Charles, 3 place Victor Hugo, 13331 Marseille, France \\ ${ }^{\mathrm{b}}$ Zoological Institute, Technical University of Braunschweig, Spielmannstr. 8, 38106 Braunschweig, Germany \\ ${ }^{\mathrm{c}}$ Department of Biology, Evolutionary Biology, University of Konstanz, 78457 Konstanz, Germany \\ ${ }^{\mathrm{d}}$ Impasse Jean Galot, 97354 Montjoly, Guyane Française \\ e 2 rue Doct. Floch, 97310 Kourou, Guyane Française \\ ${ }^{\mathrm{f}}$ Molecular Ecology Laboratory, School of Biological Sciences, University of Canterbury, Private Bag 4800, Christchurch, New Zealand
}

Received 25 April 2006; revised 27 November 2006; accepted 1 December 2006

Available online 23 December 2006

\begin{abstract}
Few studies to date have examined genetic variability of widespread tropical amphibian species over their distributional range using different kinds of molecular markers. Here, we use genetic data in an attempt to delimit evolutionary entities within two groups of Neotropical frogs, the Scinax ruber species group and the Rhinella margaritifera species group. We combined mitochondrial and nuclear markers for a phylogenetic (a total of $\sim 2500 \mathrm{bp}$ ) and phylogeographic study ( $\sim 1300 \mathrm{bp}$ ) to test the reliability of the currently accepted taxonomic assignments and to explore the geographic structure of their genetic variation, mainly based upon samples from the French Guianan region. Phylogenetic analyses demonstrated the polyphyly of Scinax ruber and Rhinella margaritifera. S. ruber consists of six lineages that may all merit species status. Conflicting signals of mitochondrial and nuclear markers indicated, among some Scinax lineages and species, the possibility of ongoing hybridization processes. $R$. margaritifera consisted of 11 lineages which might represent distinct species as well. Phylogeographic analyses added further information in support of the specific status of these lineages. Lineages of low divergence were found in sympatry and were reciprocally monophyletic for mitochondrial as well as nuclear genes, indicating the existence of young lineages that should be awarded species status. Our results highlight the utility of combining phylogenetic and phylogeographic methods, as well as the use of both mitochondrial and nuclear markers within one study. This approach helped to better understand the evolutionary history of taxonomically complex groups of species. The assessment of the geographic distribution of genetic diversity in tropical amphibian communities can lead to conclusions that differ strongly from prior analyses based on the occurrence of currently recognized species alone. Such studies, therefore, hold the potential to contribute to a more objective assessment of amphibian conservation priorities in tropical areas.
\end{abstract}

Keywords: Amphibia; Tyrosinase; 18S rDNA; Mitochondrial genes; Hylidae; Scinax; Bufonidae; Rhinella; Neotropics

\section{Introduction}

The Neotropics are the region of highest species richness in the world (Gaston and Williams, 1996; Myers et al., 2000; Wilson, 1992). Amphibians are one group in which this high

\footnotetext{
* Corresponding author. Fax: +64 33642590.

E-mail address: afo23@student.canterbury.ac.nz (A. Fouquet).
}

species diversity is obvious, with 2750 described species in Central and South America representing 48\% of the world's total (Young et al., 2004). The increasing utilization of molecular data has reinforced the conclusion that morphological evolution in amphibians is often cryptic (e.g. Chek et al., 2001; Cherry et al., 1977; Hass et al., 1995; Maxson, 1984; Richards and Moore, 1996; Stuart et al., 2006) and has led to a revitalization of amphibian taxonomy. Many groups of 
amphibians are morphologically conserved and depauperate in obvious external characters. This and a high degree of convergence led to numerous misinterpretations of anuran phylogeny which were based on morphological traits alone (e.g. Bossuyt and Milinkovitch, 2000; Chiari et al., 2004; Vences et al., 2003). Therefore, and despite important recent advances, amphibian systematics have remained poorly resolved (e.g. Darst and Cannatella, 2004; Faivovich et al., 2005; Frost et al., 2006; Grant et al., 2006; Graybeal, 1997; Ruvinsky and Maxson, 1996; Vences et al., 2003), and amphibian diversity seems to be still largely underestimated in terms of the number of species, and genera as well as families (e.g. Biju and Bossuyt, 2003; Borkin et al., 2004; Bossuyt et al., 2004; De la Riva et al., 2000; Meegaskumbura et al., 2002). Numerous species have recently been described (Duellman, 1999; Glaw and Köhler, 1998; Köhler et al., 2005) and many widely distributed species of frogs are suspected to contain several new species (for the Neotropical region: Chek et al., 2001; De la Riva et al., 2000; Grant et al., 2006; Lescure and Marty, 2000; Lougheed et al., 1999; Vences et al., 2003).

When populations of a taxon are readily sampled and distributions are well known it is possible to study its phylogeographic patterns (Avise, 2000). However, this is rarely the case for the vast majority of amphibians that occur in the tropics. Molecular information for single individuals or single populations of amphibians are therefore of limited value in determining species status. Moreover, population genetic studies of anurans typically discovered very high genetic diversities compared to other vertebrate groups (e.g. Vences et al., 2005a,b). Although high intraspecific genetic divergences certainly occur in many amphibians, the high incidence of such patterns is probably also indicative of taxonomic practice, i.e., the failure to discover cryptic species (Chek et al., 2003; Crawford, 2003; Lougheed et al., 1999). Because most frogs are expected to be of low vagility and highly philopatric (Blaustein et al., 1994; Duellman, 1982), geographical structure and endemism would be expected to be high. However, so little is known of the diversification and age of lineages in Neotropical frog taxa that current spatial proximity between populations might also be the result of a long history of expansions and contractions of ranges. Geographic and genetic fragmentation is so common in tropical amphibians that Wynn and Heyer (2001) have questioned whether widespread species of tropical amphibians exist at all. Considering the effects of global amphibian declines (Hanken, 1999; Houlahan et al., 2000; Stuart et al., 2004), numerous, still undescribed species are probably vanishing at alarming rates in the Neotropics.

The northeastern part of South America as delimited biogeographically by Hoogmoed (1979) is called the Guianan region. The endemism of frogs in this region is currently considered to be significant, but low compared to the Andes and the Brazilian Atlantic forest (Duellman, 1999) because many frog species are believed to have large ranges in Amazonia as well as the Guianas. Main factors that are thought to have shaped genetic diversity in South America include geological and climatological historical events and changes in the distribution of forested areas (Frailey et al., 1989; Haffer, 1969, 1990, 1997; Nores, 1999; Räsänen et al., 1991, 1990). On a broad scale, French Guiana might be on a borderline segregating east and west assemblages of plants (De Granville, 1982), fishes (Boujard et al., 1997; Jegu and Keith, 1999) and frogs (Lescure and Marty, 2000). On a smaller geographic scale, the central region near Saül, the northeastern area near Cayenne and the northwest region might have played a role as refugium for forest specialists during past climatic oscillations (Charles-Dominique et al., 1998; De Granville, 1988, 1982; Duellman, 1982; Dutech et al., 2003; Ledru et al., 1997). However, genetic studies on tropical trees (Caron et al., 2000; Dutech et al., 2004, 2000, 2003) and rodents (Steiner and Catzeflis, 2003; Van Vuuren et al., 2004) provided preliminary information on the genetic geographical structure of species within French Guiana that fit only partially with this refugia hypothesis.

The available evidence of usually strong phylogeographic structure in amphibians supports their use as model group to understand patterns of local differentiation and endemism. We tested the hypothesis of high cryptic genetic and species diversity in French Guiana by studying two widely distributed and abundant groups of frog species, the Scinax ruber group and the Rhinella margaritifera group: the genus Scinax is distributed from southern Mexico to eastern Argentina and contains 86 described species of treefrogs (Frost, 2004). Eight previously described species are currently considered to inhabit French Guiana (Table 1 Supplementary material). S. ruber, S. cruentommus, and $S$. $x$-signatus are widely distributed species throughout the Guianas and Amazonia and are suspected to be of unresolved species status throughout their range (De la Riva et al., 2000; Duellman and Wiens, 1993; Frost, 2004; Lescure and Marty, 2000). Scinax ruber and S. boesemani inhabit open areas whereas $S$. cruentommus, $S$. sp. 1 and $S$. $x$-signatus inhabit the rainforest. The Rhinella margaritifera group is distributed throughout Amazonia and the Guianas and comprises 14 described species of toads (Frost, 2004) that all inhabit the rainforest floor. Morphological analyses of specimens from all over South America indicated that this complex may contain many undescribed species, most having small, allopatric distributional ranges (Hoogmoed, 1990). De la Riva et al. (2000) citing Hoogmoed (1990) and Hass et al. (1995), suggests that four species could exist in Bolivia alone, while Vélez-Rodríguez (2004) hypothesizes that no less than 15 species occur in Colombia. Hass et al. (1995) and recently Pramuk (2006) revealed the existence of a multitude of genetic lineages in this group. Hass et al. (1995) used quantitative immunological techniques and confirmed the presence of two different species in French Guiana: one with pronounced cranial crests (R. margaritifera sensu stricto), and a second one without crests (Bufo typhonius group sp.1 in Lescure and Marty (2000)). Hoogmoed (1990) further suggested that a third species, of smaller size and with a sharper nose and different 
call inhabits French Guiana (Lescure and Marty, 2000). More recently, Haas (2004) suggested the occurrence, in the northern part of French Guiana, of three sympatric species of the group, without providing evidence, however.

Here, we apply an integrative phylogenetic and phylogeographic approach using mitochondrial (16S and $12 \mathrm{~S}$ rDNA) and nuclear data (18S rDNA and tyrosinase) to test whether or not the current species delimitations are consistent with the molecular phylogenetic history. The comparison of the patterns given by these different sets of molecular markers can be meaningful for species delineation and to infer information about their evolutionary history and their relationships.

\section{Materials and methods}

\subsection{Biological samples}

Tissue samples (liver or muscle) of 41 Scinax ruber, 12 S. x-signatus, 10 S. boesemani, 21 S. cruentommus, 8 S. sp. 1 , 2 S. jolyi, 2 S. proboscideus, 3 S. nebulosus, 1 Dendropsophus nanus, 1 D. leucophyllatus, 1 Sphaenorhynchus lacteus, 52 Rhinella margaritifera, 1 Rhaebo guttatus, 1 Chaunus granulosus, 1 Dendrophryniscus minutus, 1 Atelopus flavescens, and 1 Atelopus barbotini (see Noonan and Gaucher, 2005) were obtained from different localities of French Guiana
(Fig. 1). Sequences of 14 of the hylid samples have already been published in Salducci et al. (2002, 2005) (Appendix 1 Supplementary material). In addition, six Scinax cruentommus and five Rhinella margaritifera tissue samples were collected by Philippe Gaucher (DIREN Mission Parc French Guiana), four additional samples of $S$. ruber from Ecuador were sampled by Kathryn Elmer and one was provided by the Netherlands Museum of Natural History. A sample of Scinax elaeochrous from Costa Rica was made available from the tissue collection of the Museum of Vertebrate Zoology (Berkeley), and a sample of $S$. sp. 2 from Colombia was provided by Adolfo Amézquita. Further sequences available from GenBank (40 mitochondrial and 26 nuclear sequences) were included as well (Appendix 1 Supplementary material).

Identifications of specimens were mainly based on the only available comprehensive reference on anurans of French Guiana (Lescure and Marty, 2000). However, the taxonomy used by these authors may in some aspects be conflicting with the classification used in other parts of the Neotropics. For example, Scinax $x$-signatus is described by many authors (e.g. Bourne and York, 2001; Gorzula and Señaris, 1998; Hoogmoed, 1979) as an inhabitant of open areas that has been often and is still confounded with S. ruber (Gorzula and Señaris, 1998). In contrast, in French Guiana, Scinax $x$-signatus is considered to be an explosive

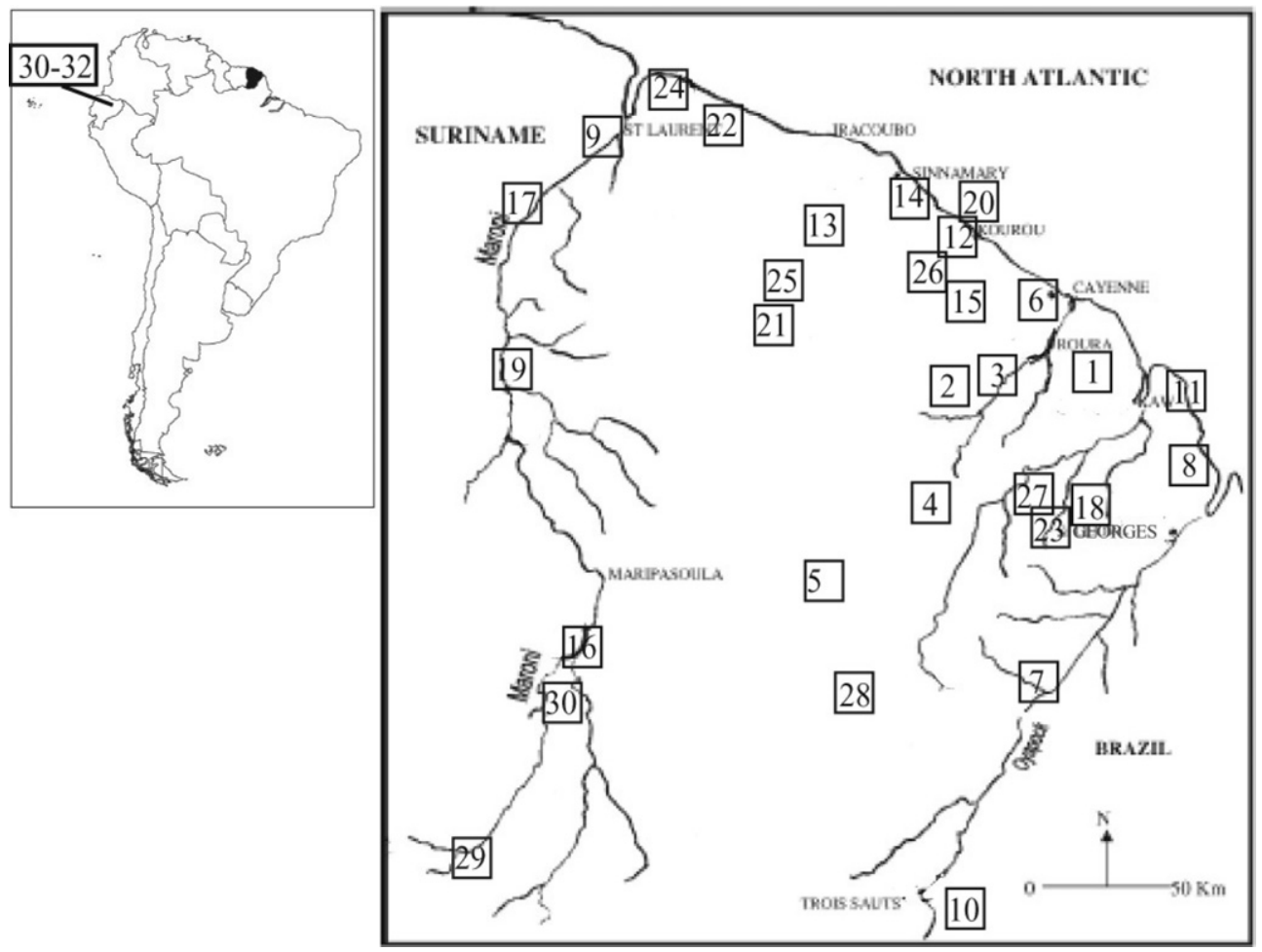

Fig. 1. Map of French Guiana showing the collection localities. $\odot$ Service du Patrimoine Naturel M.N.H.N. - Paris, 2000. Kaw $=1$; La Compté $=2$; Cacao = 3; Nouragues =4; Saül = 5; Cayenne =6; Camopi =7; Ouanary = ; St Laurent =9; Trois-saut = 10; Montagne d'Argent = 11; Kourou =12; Petit-Saut = 13; route CSG Sinnamary = 14; Montsinnery=15; Antecum Pata =16; Apatou=17; route Regina St.-George = 18; Grand Santi = 19; Ile royale $=20 ;$ Crique Grand Leblond $=21 ; \mathrm{km} 7$ on $\operatorname{road} 8=22 ;$ Mataroni $=23 ;$ Mana $=24 ;$ Piste St Elie $=25 ;$ Montagne des Singes $=26 ;$ Cisame $=27 ;$ Mt Barka $=28$; Trijonction $=29$; Litany $=30$; Jatun Sacha $($ Napo, Ecuador $)=31$; AUCA14road (Orellana, Ecuador $)=32$; Comunidad Serena $($ Napo, Ecuador $)=33$. All localities are in French Guiana except for 31-33. 
breeder restricted to forests. Moreover, Gorzula and Señaris (1998) provide a drawing of this species that does not seem to correspond to the species in French Guiana. Similar doubts exist for the validity of Scinax cruentommus for French Guianan populations. We also use the name Scinax sp. 1 from Lescure and Marty (2000) for a Scinax species that remains to be identified or described. However, these taxonomic uncertainties do not invalidate any of the conclusions from the work presented here.

Based on our personal observations in the field, we used the term "syntopic" for lineages breeding exactly in the same spot or only few meters away from each other, "sympatric" for lineages occurring in at least one shared locality but which have not been observed in the exact same place and "allopatric" for lineages that do not share any locality.

\subsection{DNA protocols}

Total DNA was extracted with standard phenol-chloroform methods. Two mitochondrial (mt) and two nuclear (nu) DNA fragments were amplified by standard PCR techniques. Primers used for amplification were those described by Salducci et al. (2005) for $16 \mathrm{~S}$ and $12 \mathrm{~S}$, by Bossuyt and Milinkovitch (2000) for tyrosinase, and by Miquelis et al. (2000) for $18 \mathrm{~S}$ rDNA. The chosen molecular markers previously have been used successfully to assess the relationships among orders, families and species of amphibians (Hay et al., 1995; Ruvinsky and Maxson, 1996; Vences et al., 2000). For nuclear markers it is of foremost importance to ascertain that orthologous and not paralogous genes are analysed. According to Hoegg et al. (2004) only one copy of the tyrosinase gene exists in tetrapods, and we are therefore confident that our analysis is based on orthologous gene fragments for all samples.

PCR was performed as described in Salducci et al. (2005). Furthermore, 66 sequences of 570 bp of the mitochondrial cytochrome $b$ gene were obtained for a subset of Scinax species to obtain higher support for a conflicting phylogenetic analysis see below; primers used were: MVZ15-L; MVZ18-H, MVZ25-L (Moritz et al., 1992). Sequences were resolved on automated DNA sequencers (ABI 3700).

\subsection{Molecular analysis}

Preliminary alignment of the sequences was performed with Clustal X (Thompson et al., 1997) with an opening gap cost equal to 6. Each alignment was compared with available secondary structures (12S and 16S) (Van de Peer et al., 1998) as described in Salducci et al. (2002), or with the reading frame (tyrosinase). The analyses were performed on 368 (Scinax)-387 (Rhinella) aligned bp of the 12S rDNA gene, $413-411 \mathrm{bp}$ of the $16 \mathrm{~S}$ rDNA gene, 388-539 bp of the tyrosinase gene and $1299-1325 \mathrm{bp}$ of the 18S rDNA gene. We used Gblocks 0.91b (Castresana, 2000) to eliminate poorly aligned positions of the mitochondrial sequences of ambiguous homology for phylogenetic analysis $(45 \mathrm{bp}$ for Scinax and $34 \mathrm{bp}$ for Rhinella). All sequences obtained in this study have been deposited in GenBank (Appendix 1 Supplementary material; EF217430-EF372235).

\subsubsection{Phylogenetic analyses}

To test if analyses of combined DNA sequences of different genes can be conducted, the partition homogeneity test (PHT) (Farris et al., 1994) was used to compare the two mitochondrial genes (12S and 16S) and the two nuclear genes (tyrosinase and 18S), and to compare nuclear with mitochondrial genes.

Saturation plots were constructed in order to determine whether particular positions or classes of substitutions needed to be weighted or excluded prior to phylogenetic analyses (Grant and Kluge, 2003). We visualized the saturation by plotting the distance in transitions and transversions versus the total distance.

Bayesian phylogenetic analysis was performed with MrBayes 3.1 (Ronquist and Huelsenbeck, 2003). maximum likelihood (ML) trees were calculated using PAUP*, version 4.0b10 (Swofford, 2002). The distance matrix were computed with MEGA 2.1 (Kumar et al., 2001). We used the software Modeltest version 3.6 (Posada and Crandall, 1998) to choose the substitution model that best fits our data using the AIC criterion. These models were subsequently used for Bayesian and ML analyses. Each Bayesian analyses consisted of $2.0 \times 10^{7}$ generations with a random starting tree and four Markov chains (one cold) sampled every 1000 generations. Adequate burn-in was determined by examining a plot of the likelihood scores of the heated chain for convergence on stationarity.

Confidence in the phylogenetic grouping for ML was assessed by the bootstrap method (Efron, 1979; Felsenstein, 1985) with 1000 pseudoreplicates with the heuristic search option, tree bisection reconnection branch swapping (TBR) and 10 random taxon addition replicates. Trees were rooted on D. leucophyllatus, D. nanus, and S. lacteus for Scinax and on D. minutus, A. flavescens and A. barbotini for Rhinella.

The partition homogeneity test did not reject the null hypothesis of congruence between mitochondrial $12 \mathrm{~S}$ and 16S fragments (Scinax $P=0.239$; Rhinella $P=0.516$ ) nor between nuclear tyrosinase and $18 \mathrm{~S}$ fragments (Scinax $P=0.68$; Rhinella $P=1$ ) indicating the possibility for their combined analysis. The test did reject the null hypothesis of congruence of the included mitochondrial vs. nuclear fragments for Scinax $(P=0.028)$, but not in Rhinella $(P=1)$.

Consequently, we used the following data partitions:

1. $12 \mathrm{~S}+16 \mathrm{~S}$ for phylogeny using all the haplotypes without ambiguously aligned positions and for phylogeography using all the individuals and all the positions.

2. Tyrosinase and $18 \mathrm{~S}$ for phylogeny using only one representative for each clade previously identified in the mitochondrial trees, and because we obtained only a few $18 \mathrm{~S}$ sequences for each clade.

3. Tyrosinase for phylogeography using all the individuals. 


\subsubsection{Phylogeography}

Minimum spanning networks were calculated using TCS 1.21 (Clement et al., 2000), with a 95\% connection limit, separately on the mitochondrial genes and on the nuclear gene (tyrosinase). Our sampling being heterogeneous and scarce particularly for some remote populations, we considered it to be too premature to infer significance of the phylogeographical patterns observed by statistical tests such as Nested Clade Analyses. Because some haplotypes and haplogroups were not connected to each other with the $95 \%$ limit of probability of parsimony as used by TCS, we attempted to connect these haplotypes by decreasing the connection probability up to a minimum of $90 \%$.

\section{Results}

\subsection{Phylogenetic analyses}

One hundred and six 16S rDNA and 106 12S rDNA, 100 tyrosinase and $1718 \mathrm{~S}$ sequences were available for the analysis of Scinax (including outgroups). Sixty-five 16S rDNA and $6512 \mathrm{~S}$ rDNA, 55 tyrosinase and nine $18 \mathrm{~S}$ sequences were available for the Rhinella margaritifera group (including outgroups). Of all the samples, only five samples of Scinax ruber, two of S. cruentommus, three of $R$. margaritifera and $C$. granulosus have not been sequenced for the tyrosinase fragment.

\subsubsection{Phylogenetic analysis of Scinax}

Hierarchical likelihood tests implemented in Modeltest (Posada and Crandall, 1998) selected a GTR + I + G substitution model as best fitting the combined mitochondrial data with base frequencies $(\mathrm{A}=0.3439 ; \mathrm{C}=0.2277$; $\mathrm{G}=0.1858)$ and substitution matrix (5.1976; 14.8577; $8.7883 ; 1.3455 ; 42.3624 ; 1)$ estimated from the data, a proportion of invariable sites of $P$ invariant $=0.2511$ and a gamma distribution shape parameter of $\alpha=0.5217$. For the combined nuclear data a $\mathrm{HKY}+\mathrm{I}+\mathrm{G}$ substitution model was determined to be the best model with base frequencies $(A=0.2291 ; C=0.2499 ; G=0.2852)$, a Tratio $=2.1720$ estimated from the data, a proportion of invariable sites of $P$ invariant $=0.7466$ and a gamma distribution shape parameter $\alpha=0.9939$. Relationships among lineages of the Scinax ruber species group were poorly resolved with the mitochondrial data. However, all species previously identified correspond to homophyletic lineages except for $S$. ruber. Indeed, six lineages appeared within this species (Fig. 2a): four in French Guiana, one formed by the haplotype from Ecuador and one by the haplotype from Peru. The haplotype from Guyana clustered with one from French Guiana (S. ruber C).

The taxon Scinax ruber C nested within the $S$. ruber A clade in the tree obtained by Bayesian analyses, although support from posterior probability was low, position of this group was unsupported with ML and displayed a long branch. To solve this uncertainty, we performed an additional analysis adding $570 \mathrm{bp}$ of the cytochrome $b$ to a mitochondrial dataset comprising Scinax ruber A, B, C, $S$. $x$-signatus and $S$. nasicus, and rooted with $S$. cruentommus (a partition homogeneity test of cytochrome $b$ vs. $12 \mathrm{~S}+16 \mathrm{~S}$ resulted in $P=1)$. The best model fitting the combined data following the AIC criterion was TVM + G (base composition $(A=0.226 ; C=0.233 ; G=0.219)$; substitution matrix $(0.614 ; 8.512 ; 2.246 ; 0.205 ; 8.512)$; gamma distribution shape parameter $\alpha=0.1796)$. This combined analysis unambiguously supported the separate position of $S$. ruber C under all methods of tree reconstruction used (Fig. 2b).

One individual identified as Scinax $x$-signatus had a haplotype belonging to the lineage of $S$. ruber C (not marked in Fig. 2 but see below). Scinax ruber E was strongly divergent from the other lineages of $S$. ruber ( $p$-distances 0.136-0.143) and grouped without ambiguity with $S$. fuscovarius. Scinax ruber A emerges as sister taxon of $S$. x-signatus with high support (96/78) (Fig. 2b), and with a low genetic distance (pairwise distance between $S$. ruber A and $S$. $x$-signatus $=0.006$; see Table 2a Supplementary material). Based on these results, Scinax ruber is determined to be a paraphyletic taxon. Furthermore, two distinct lineages can also be distinguished within S. boesemani (Fig. 2a).

Based on nuclear data, Scinax $x$-signatus is unambiguously placed outside the $S$. ruber A + B clade. Hence, the relative positions of $S$. ruber A, B, C and $S$. x-signatus are incongruent between the nuclear and mitochondrial topologies (Fig. 2a-c). A Shimodaira-Hasegawa (Shimodaira and Hasegawa, 1999) test clearly showed significant differences between the likelihoods of these topologies (for the nuclear dataset $p=0.02$ and for the $\mathrm{mt}$ dataset $p=0.003$ ).

\subsubsection{Phylogenetic analysis of Rhinella}

Modeltest selected a GTR + I + G substitution model as best fitting the combined mitochondrial data with base frequencies $(\mathrm{A}=0.3208 ; \mathrm{C}=0.2219 ; \mathrm{G}=0.1859)$ and substitution matrix $(8.4255 ; 34.9686 ; 26.6056 ; 0 ; 121.2654)$ estimated from the data, a proportion of invariable sites of $P$ invariant $=0.2919$ and a gamma distribution shape parameter of 0.4109 . For the combined nuclear data a $\operatorname{TrN}+$ I substitution model best fitted the data, with base frequencies $(A=0.2368 ; C=0.2528 ; G=0.2745)$ and substitution matrix $(1 ; 2.6127 ; 1 ; 1 ; 5.2347)$ estimated from the data and a proportion of invariables sites of $P$ invariant $=0.8306$.

The Rhinella margaritifera species group + "Bufo" ocellatus form a monophyletic group ("B. ocellatus" is supported as the sister taxon of the $R$. margaritifera species group according to Pramuk (2006)) of 14 divergent lineages (Fig. 3a). The most basal lineage, Rhinella margaritifera E, corresponds to "Bufo typhonius" sp. 1, and $R$. margaritifera A corresponds to B. margaritifer of Lescure and Marty (2000). Rhinella margaritifera is paraphyletic due to the relative positions of $R$. dapsilis, $R$. castaneotica, "Bufo" ocellatus and the different lineages of $R$. margaritifera. Rhinella margaritifera $\mathrm{D}$ has been identi- 

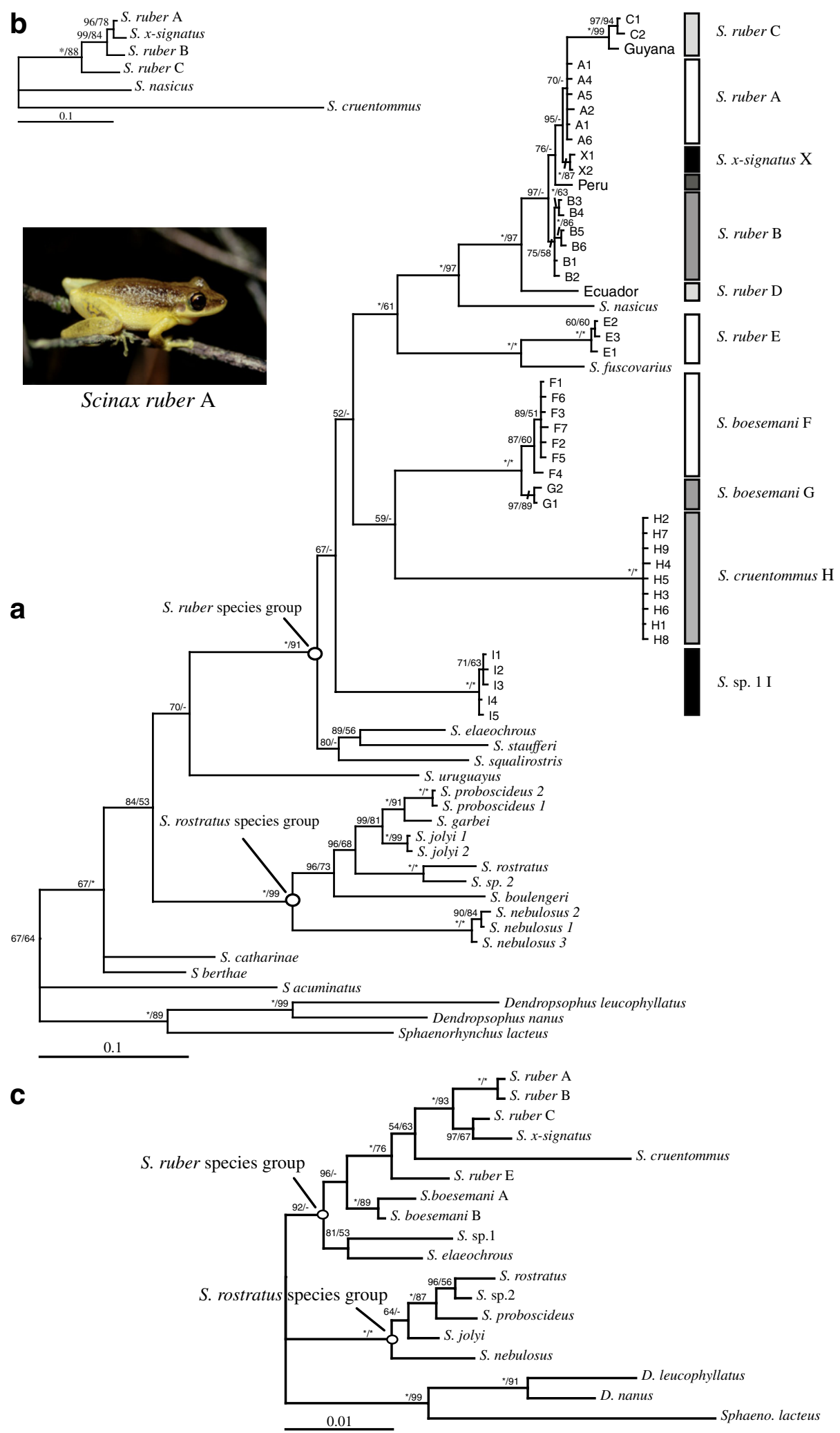

Fig. 2. (a) Phylogram of lineages and species of Scinax, based on a Bayesian analysis of mitochondrial DNA sequences (781 bp of 16S rDNA and 12S rDNA), rooted with Sphaenorhynchus lacteus, Dendropsophus leucophyllatus, and D. nanus. Support values are Bayesian posterior probabilities and ML, nonparametric bootstrap values (1000 replicates) in percent. Asterisks indicate values of $100 \%$. No values are given if below $50 \%$ or "-" if the respective analysis was not supporting the topology shown. (b) Phylogram based on a Bayesian analysis on a more extended mitochondrial DNA sequence dataset (1332 bp of cytochrome $b, 16 \mathrm{~S}$ rDNA and 12S rDNA), rooted on S. cruentommus. Support values on phylogram represent posterior probabilities and ML, bootstrap values in percent (1000 replicates), respectively. (c) Phylogram from a Bayesian analysis of nuclear DNA sequences (1677 bp of 18S rDNA and tyrosinase), rooted on Sphaenorhynchus lacteus, Dendropsophus leucophyllatus, and D. nanus. Only one individual by previously identified major lineage were available for the $18 \mathrm{~S}$ fragment and therefore only these ones were used. Support values as in (a). 
a

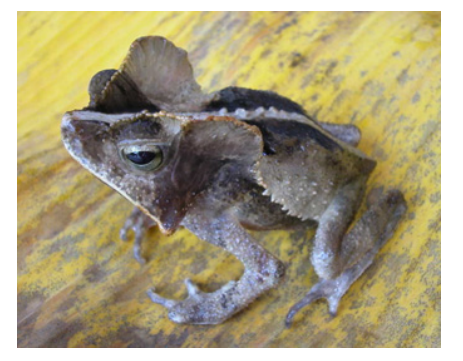

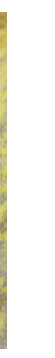

RMA1
RMA10
RMA2
RMA7
RMA
RMA8
RMA3
RMA6
RMA4
RMA5
RMA9

R. margaritifera A

$1 / 84$

RMB

$\leftarrow$ Rhinella

R. margaritifera $\mathrm{B}$

RMC

RMD1

R. margaritifera $\mathrm{C}$

R. margaritifera $\mathrm{D}$

$R$. cf. margaritifera 6-Brazil

$99 /-6$

$-\quad$. cf. margaritifera 5-Peru

$95 / 60-R$. cf. margaritifera 2-Ecuador

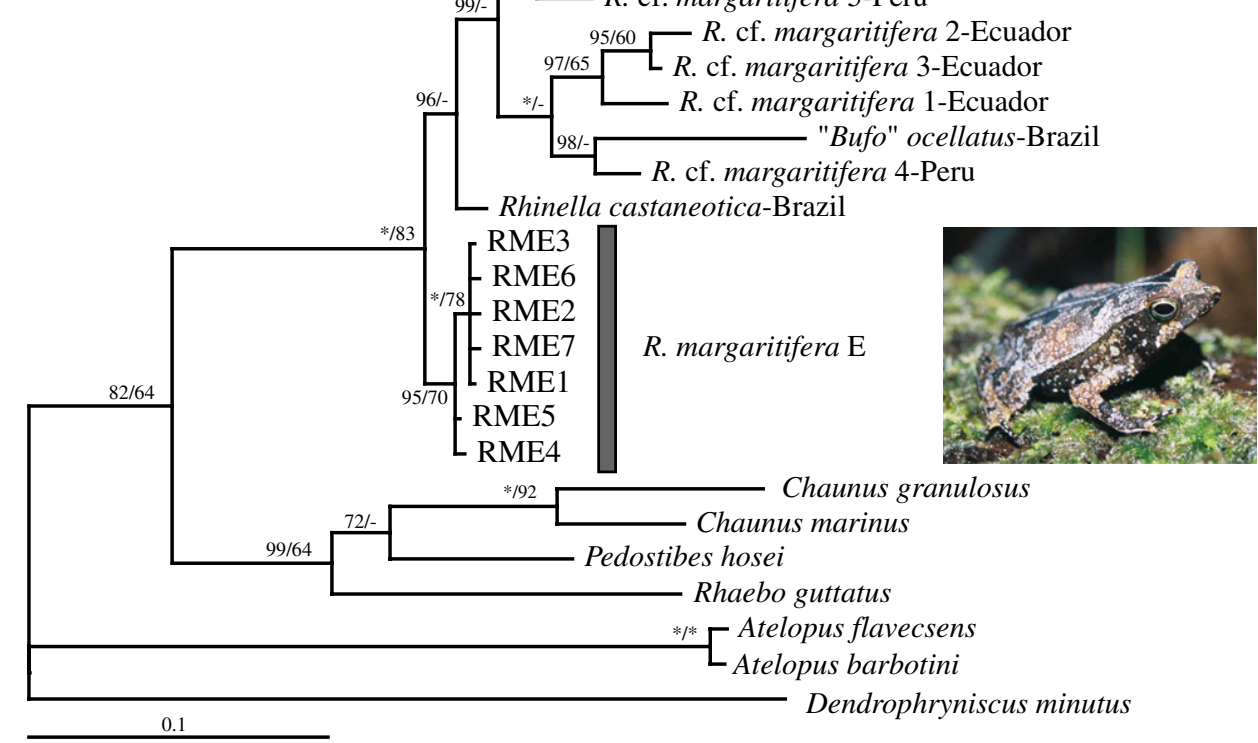

b

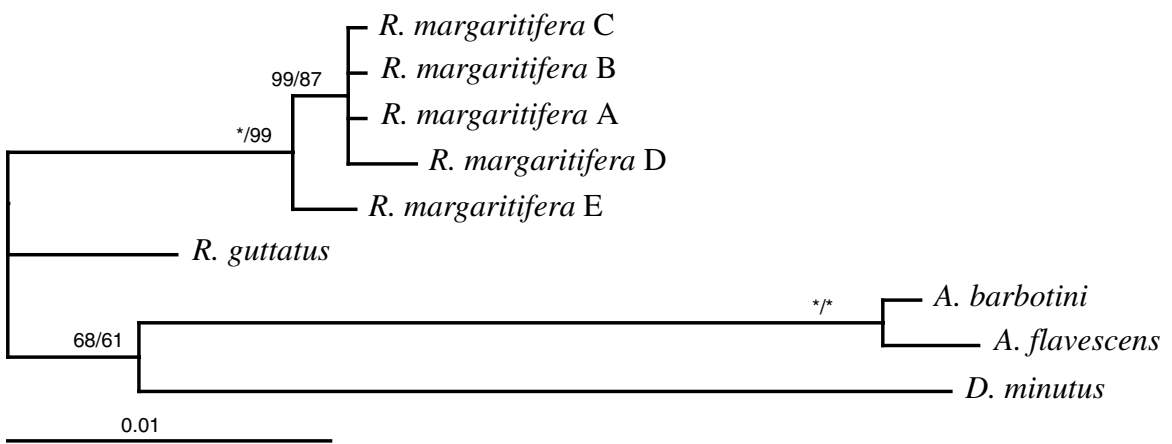

Fig. 3. (a) Phylogram of lineages in the Rhinella margaritifera group and other species of Bufonidae, from a Bayesian analysis of mitochondrial DNA sequences (798 bp of 16S rDNA and 12S rDNA), rooted on Dendrophryniscus minutus, Atelopus flavescens, and A. barbotini. Support values are Bayesian posterior probabilities and ML nonparametric bootstrap values in percent. Asterisks indicate values of $100 \%$. No values are given if below $50 \%$ or "_" if the respective analysis was not supporting the topology shown. (b) Phylogram from a Bayesian analysis of nuclear DNA sequences (1864 bp of $18 \mathrm{~S}$ rDNA and tyrosinase), rooted on Atelopus flavescens and A. barbotini. Only one individual per previously identified major lineage were available for the $18 \mathrm{~S}$ fragment and therefore only these ones were used. Support values as in (a).

fied by two of us (CM and MB) as "Bufo typhonius" sp. 1 because the individuals lack cranial crests. Except the fact that Rhinella margaritifera A, B, and C could not be distinguished based on nuclear markers there was no incongruence between the nuclear and mitochondrial data (Fig. 3b).

\subsection{Phylogeography}

The TCS analysis of the mitochondrial data from the Scinax ruber species group produced six unconnected haplotype networks (Fig. 4, see also Fig. 1 Supplementary material). For the lineages Scinax ruber A, S. ruber B and 

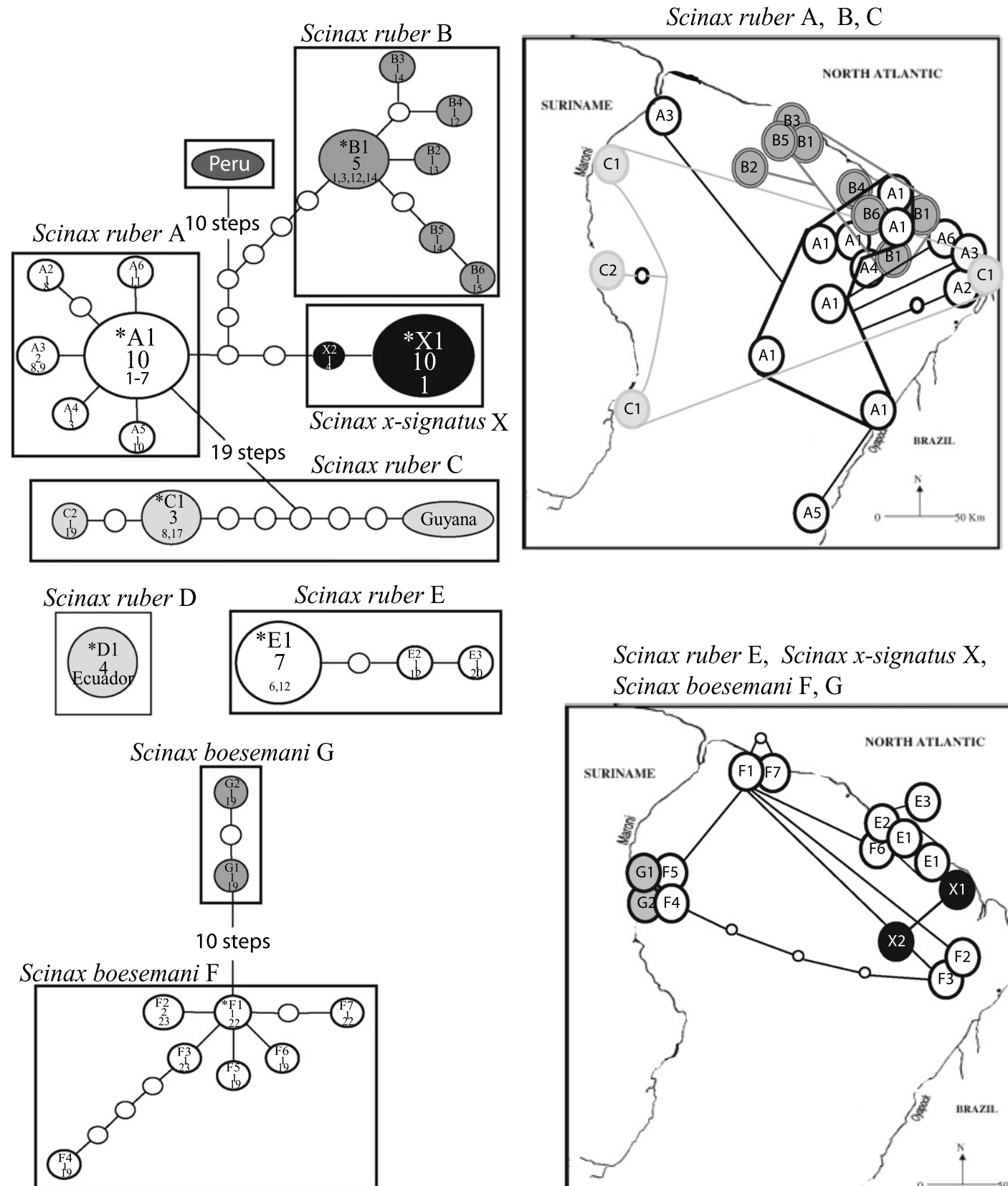

Scinax cruentommus $\mathrm{H}$

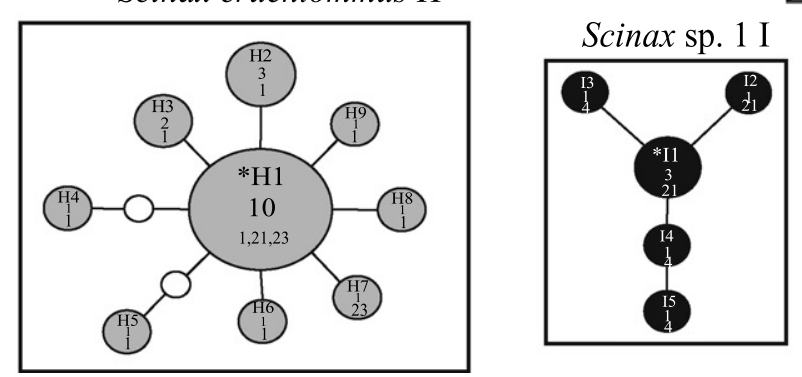

Scinax ruber E, Scinax x-signatus X, Scinax boesemani F, G

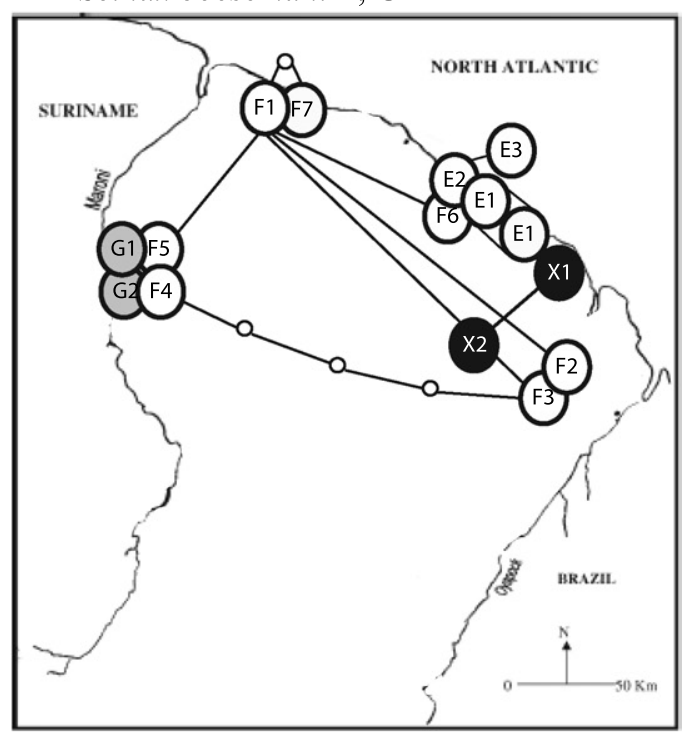

Fig. 4. Haplotype networks for the major Scinax lineages sampled, based on mitochondrial DNA sequences (763 bp of 12S rDNA and 16S rDNA). Asterisks indicate the central haplotype, and from top to bottom the numbers represent the name of each haplotype, the number of individuals and of the localities where it has been sampled. S. ruber is divided into six haplogroups.

S. $x$-signatus we performed an independent network reconstruction to estimate which haplotypes are ancestral. Locations of the haplotypes and their connections have been reported on the maps when a geographic structure of genetic variation was obvious, whereas only the distribution of the general lineages is plotted on the maps when no 


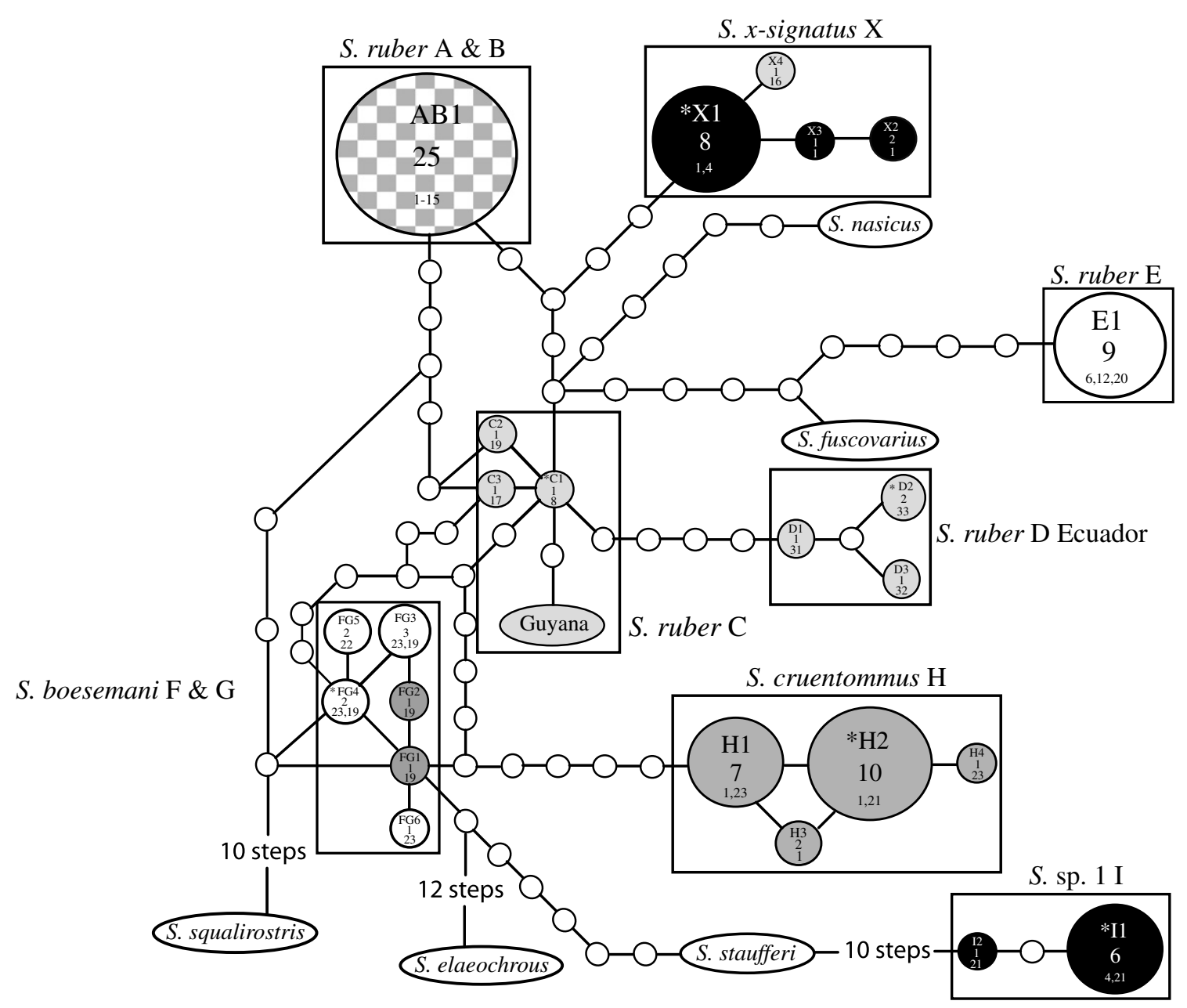

Fig. 5. Haplotype networks for the major Scinax lineages sampled, based on nuclear DNA sequences ( 360 bp of tyrosinase). From top to bottom the numbers represent the name of each haplotype, the number of individuals and of the localities where it has been sampled. The three arrows indicate the haplotypes that were assignated to a different cluster with mitochondrial data.

obvious structure could be observed. With nDNA there were three unconnected haplotype networks for the Scinax ruber species group (Fig. 5). The same analysis of mitochondrial data from the Rhinella margaritifera group produced three unconnected haplotype networks (Fig. 6) and one with nDNA (Fig. 7). Ambiguous sites of the tyrosinase fragment due to heterozygosity, had to be coded as $\mathrm{N}$, which explains the multiple connections seen in the nuclear networks.

Pairwise distances in the mitochondrial rRNA genes between haplotypes of the various major lineages from French Guiana (not considering introgressions) were 1.3$14.3 \%$ in Scinax ruber, and $1-5.1 \%$ in the Rhinella margaritifera group (Table 2 Supplementary material).

\subsubsection{Phylogeography of Scinax lineages}

3.2.1.1. MtDNA. Sequences of Scinax ruber are divided into six clades (Fig. 4). The $S$. ruber haplotype from Peru appears to belong to a taxon closer to $S$. ruber B and $S$. ruber A plus $S$. x-signatus (Fig. 4). It connected (with a $94 \%$ connection limit) with $S$. ruber A by at least 13 mutational steps and by at least 14 mutational steps with both
S. ruber B and $S$. $x$-signatus. $S$. ruber $\mathrm{C}$ connected with $S$. ruber A (with a $90 \%$ connection limit) by at least 22 steps. The haplotype from Guyana connected with $S$. ruber C by at least six mutational steps. $S$. boesemani is divided into two clades separated by ten mutational steps. Geographic structure of mitochondrial haplotypes was found among different sister lineages: Scinax ruber A appeared to be mainly distributed in the north-east of French Guiana, $S$. ruber B and $S$. ruber $\mathrm{E}$ in the central north near the coast. Scinax boesemani $\mathrm{G}$ was restricted to the west while $S$. boesemani $\mathrm{F}$ was more widespread over the north part of French Guiana (Fig. 4).

Within-group variation is geographically structured for Scinax ruber A (Fig. 4) to the east and along Oyapock River and also for $S$. boesemani F. Scinax ruber C has only been found along major rivers. $S$. $x$-signatus, $S$. ruber B, and $S$. ruber E are weakly structured (Fig. 4) and there is no clear pattern for $S$. sp. 1 and $S$. cruentommus (not shown).

3.2.1.2. Nuclear DNA. The clades here defined as Scinax ruber $\mathrm{A}$ and $\mathrm{B}$ share two haplotypes in the nuclear data set 


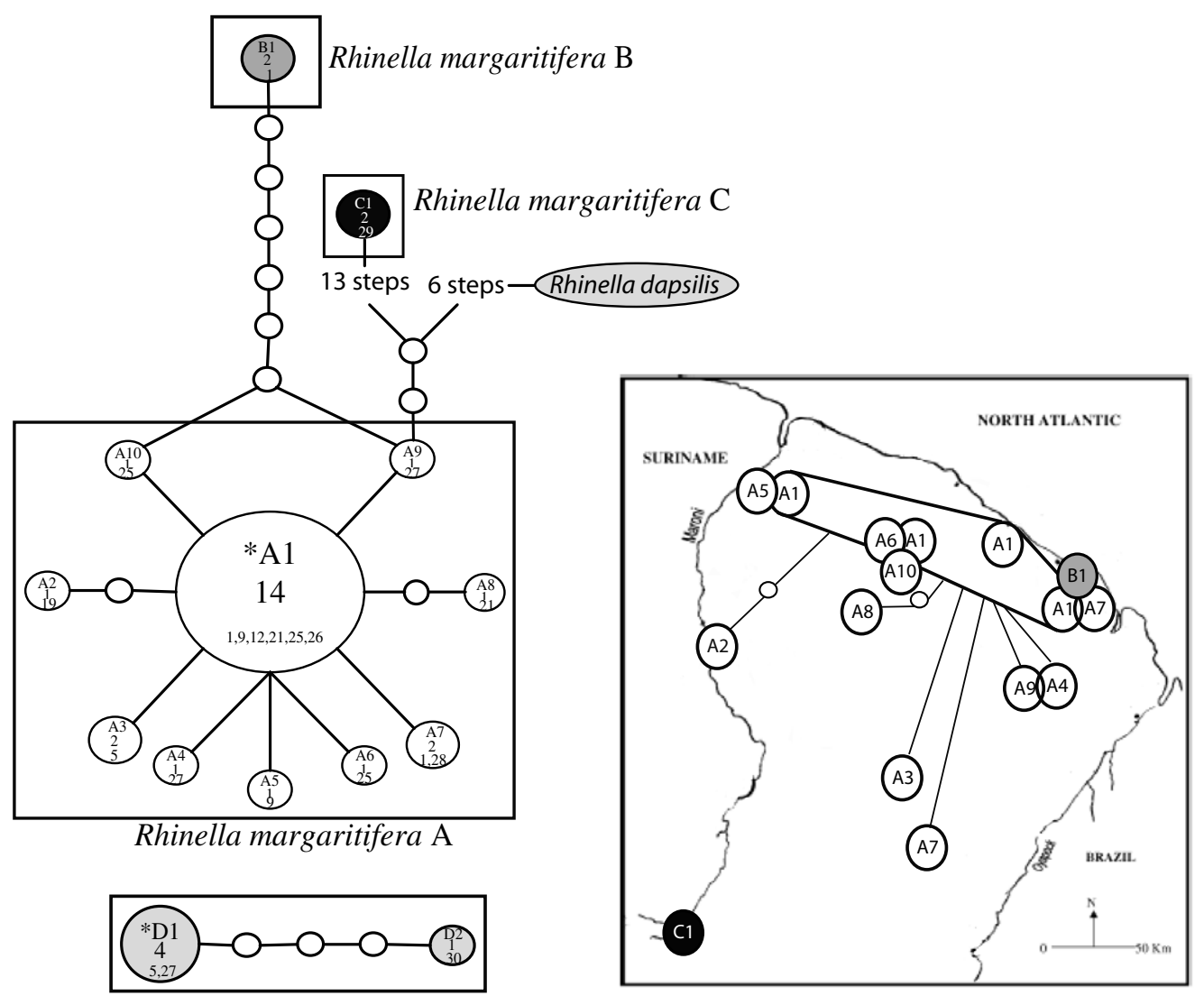

Rhinella margaritifera $\mathrm{D}$

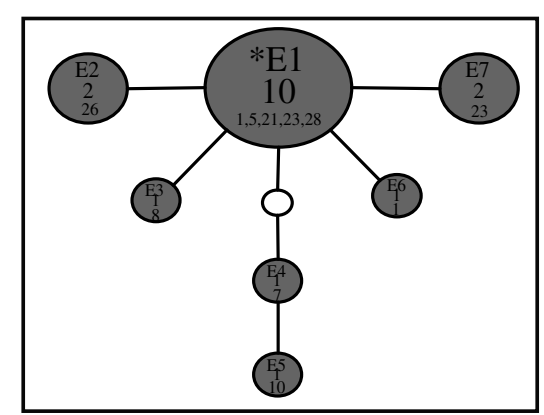

Rhinella margaritifera $\mathrm{E}$

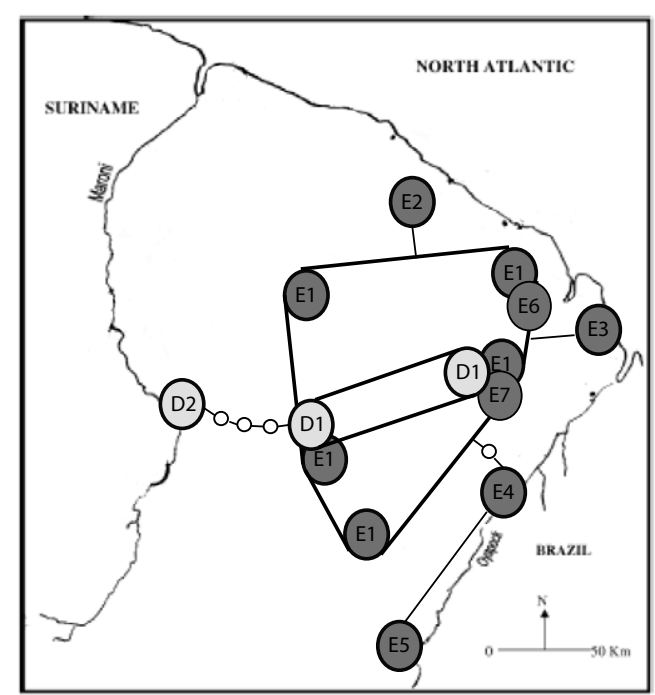

Fig. 6. Haplotype networks for the different lineages of the Rhinella margaritifera group based on mitochondrial DNA sequences (777 bp of $12 \mathrm{~S}$ rDNA and $16 \mathrm{~S}$ rDNA). Asterisks indicate the central haplotype, and from top to bottom the numbers represent the name of each haplotype, the number of individuals and of the localities where it has been sampled.

and therefore cannot be clustered separately. Similarly, the two individuals constituting $S$. boesemani G are not clearly segregated from $S$. boesemani $\mathrm{F}$ even if they have two unique haplotypes. The $S$. $x$-signatus individual which, by mitochondrial data, is nested within $S$. ruber C was affiliated to $S$. $x$-signatus in the tyrosinase network (Fig. 5). This network clearly shows a position of $S$. x-signatus outside the clade $S$. ruber A + B.

\subsubsection{Phylogeography of Rhinella lineages}

3.2.2.1. MtDNA. The five clades in the Rhinella margaritifera species group occuring in French Guiana, as identified in the phylogenetic analyses, were also retrieved in the haplotype networks. Rhinella margaritifera A comprises ten haplotypes (Fig. 6). Rhinella margaritifera B comprises two individuals separated from RMA by seven mutational steps. Rhinella margaritifera $\mathrm{C}$ is composed by one haplotype and by two 


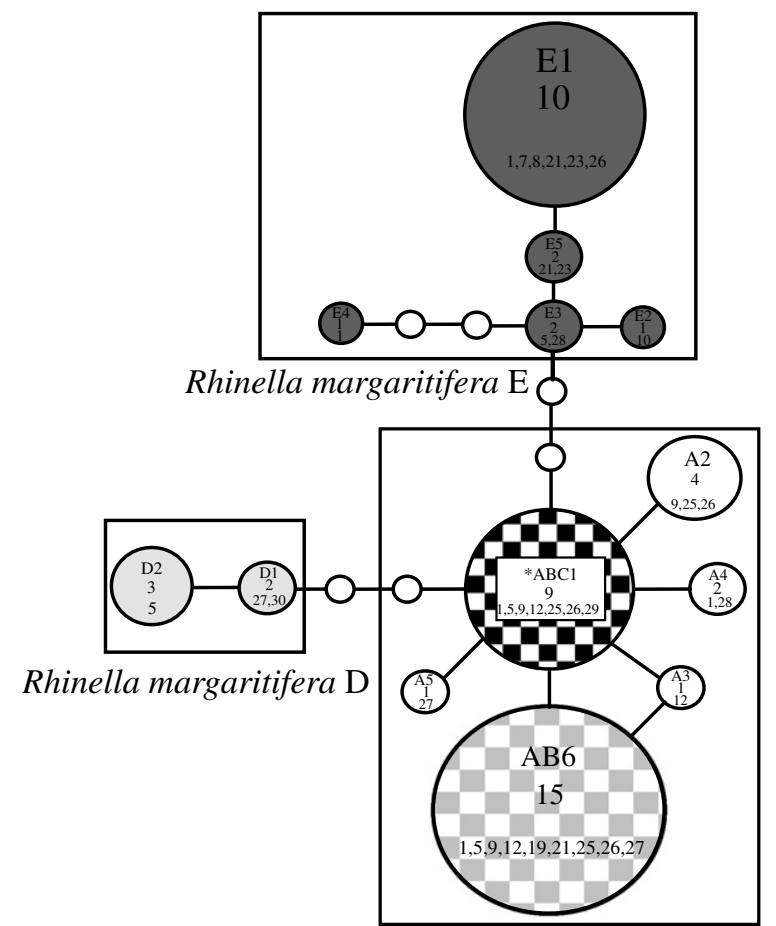

Rhinella margaritifera A, B \& C

Fig. 7. Haplotype network for the different lineages of the Rhinella margaritifera group based on nuclear DNA sequences (539 bp of tyrosinase). From top to bottom the numbers represent the name of each haplotype, the number of individuals and of the localities where it has been sampled.

individuals originating from the extreme south of French Guiana (connection to $R$. margaritifera A9 by 15 steps with $92 \%$ connection limit). Geographically, Rhinella margaritifera A haplotypes show a pattern in which the central, putatively ancestral haplotype (A1) is distributed along the northern strip of French Guiana (Fig. 6). In Rhinella margaritifera E, the pattern is less clear but the central, putatively ancestral haplotype (E1) seems to be more widely distributed, at least from central to northern French Guiana. However, a clear structure is shown by populations along the Oyapock River.

\subsubsection{Nuclear DNA. Rhinella margaritifera B shares two} different nuclear haplotypes with $R$. margaritifera A (Fig. 7). These two nuclear haplotypes correspond to individuals with $\mathrm{mt}$ haplotypes of $R$. margaritifera A but sampled in the vicinity of $R$. margaritifera B (near Kaw mountain). Rhinella margaritifera $\mathrm{C}$ shares the nuclear haplotypes with $R$. margaritifera $\mathrm{A}$, which is its central haplotype. However, one site that is likely heterozygous (C and $\mathrm{G})$ in the tyrosinase sequences of the two individuals constituting $R$. margaritifera $\mathrm{C}$ reveals that one allele is only shared by these two individuals.

\section{Discussion}

\subsection{New lineages and new species}

A precise and correct delimitation of species is essential as species are basic units of analysis in biogeography, ecology, macroevolution, biodiversity assessment and conservation. Over- or under-resolving species boundaries can lead to wrong interpretations (Sites and Marshall, 2003, 2004).

The straightforward use of the phylogenetic species concept can lead to view species not as real evolutionary entities (Goldstein et al., 2005, 2000). As advocated by Frost and Hillis (1990), for amphibians and reptiles, it would be more appropriate to consider amphibian species as monophyletic group of populations that are likely to be on independent phylogenetic trajectories under an evolutionary species concept (Wiley, 1978). In this way, one crucial point in delimiting cryptic species is to distinguish between broad admixture on one hand, and narrow contact zone or restricted hybridization on the other hand (Wake and Jockusch, 2000). Moreover, diagnostic nucleotide sites of mitochondrial haplotypes in a character-based approach to species delineation (Goldstein et al., 2005) could contradict information from nuclear genes as it has been often found in amphibians (e.g. GarciaParis et al., 2003; Kuchta and Tan, 2005; Monsen and Blouin, 2003; Sequeira et al., 2005; Wake and Jockusch, 2000; Zangari et al., 2006). Thus, species borders are better understood using a combination of different kinds of markers as underlined by Moritz (1994a,b).

In the present cases, concordance between the coalescence criterion and the isolation criterion (de Queiroz, 1998) can be employed to assume that several cryptic species are present in $S$. ruber and $R$. margaritifera. Indeed, there is no observed overlap between mitochondrial and nuclear haplotype lineages identified despite sympatry. It is rather between different species that we observed potential gene flow or remains of ancestral polymorphism, as between $S$. ruber C and $S$. x-signatus. Nevertheless, if gene flow exists between the different identified lineages of $S c i$ nax and Rhinella, it appears to be limited. Moreover, the basal position of the mitochondrial haplotype of Scinax ruber from Ecuador and the haplotypes of Rhinella margaritifera from Brazil, Ecuador and Peru provide evidence that these lineages may be representatives of different species as compared to the ones present in French Guiana.

Rhinella margaritifera $\mathrm{D}$ probably corresponds to a species whose existence has already been suggested by Hoogmoed (1990) even if we did not notice any immediate diagnostic characters in morphology or bioacoustics to distinguish it from $R$. margaritifera $\mathrm{E}$. We note that the morphology of $R$. margaritifera $\mathrm{D}$ is close to $R$. margaritifera $\mathrm{E}$ with respect to body size and absence of cranial crests, whereas it unambiguously is sister to a clade containing $R$. margaritifera $\mathrm{A}, \mathrm{B}$, and $\mathrm{C}$ based on molecular data. Thus, the presence of cranial crests in $R$. margaritifera A, B, and $\mathrm{C}$ is probably a synapomorphy of these three lineages.

Ambiguity remains whether Scinax ruber A and B should be considered different species, and the same applies to $R$. margaritifera $\mathrm{A}, \mathrm{B}$, and $\mathrm{C}$. Clear genetic differences exist in mtDNA (distance: seven steps and $d=0.013$ between $S$. ruber A and B, seven steps and $d=0.01$ between $R$. margaritifera $\mathrm{A}$ and $\mathrm{B}$, and 15 steps and $d=0.02$ between 
R. margaritifera A and C) which corresponds to different geographical ranges (Fig. 6). However, tyrosinase, the nuclear marker, showed no clear divergences (Fig. 7). The size of the fragment and the slower rate of evolution of the tyrosinase gene and slower stochastic lineage sorting are the main reasons for the lack of resolution of this nuclear marker compared with mitochondrial data. Given that these lineages present basically similar morphologies (based on external character identification), it seems obvious that they share ancestral polymorphism and retain some features of their ancestor's morphology (Jarman and Elliott, 2000). However, the position of $S$. $x$-signatus, for which the specific status is clear based on ecology and morphology, as sister taxon of $S$. ruber A (in mtDNA) without overlap in nuclear DNA lineages despite sympatry illustrates that even low genetic distances of mtDNA between groups may separate different species. The same applies for $R$. dapsilis which is the sister taxon of $R$. margaritifera $\mathrm{A}+\mathrm{B}$. We should also add that standard haplotypic diversity within species for which there is no ambiguity on their status in French Guiana such as $S$. cruentommus or $R$. margaritifera E "typhonius" is not higher than those for each cluster of $S$. ruber A, and B, and R. margaritifera A. The similar degree of diversity within these entities tends to indicate that they should be considered on a similar taxonomic status.

Amphibians are often characterized by high genetic differentiation, and intraspecific pairwise divergences of the mitochondrial rRNA (12S and 16S) genes have been found extending up to almost 6\% (Vences et al., 2005a,b). However, in most comparisons among conspecific populations values were lower, and divergences of $4-5 \%$ usually were indicative of distinct species. Pairwise divergences of around $5 \%$ distinguish several of the lineages identified herein. For instance Scinax ruber D from other $S$. ruber lineages, and Rhinella margaritifera $\mathrm{E}$ from other lineages in the species group. Scinax ruber E is even distinguished by divergences around $14 \%$ from all other lineages assigned to $S$. ruber. These divergences are therefore at a level that also in other amphibian groups has been observed to characterize distinct species. Defining new species on the basis of their genetic distances on a single DNA fragment is strongly debated (Meyer and Paulay, 2005) as some species might arise within a very short time frame (as cichlids, e.g. Joyce et al., 2005; Salzburger and Meyer, 2004) and/or hybridize. However, over a threshold, the distances between lineages can certainly be used as a preliminary indicator to identify candidate species (Vences et al., 2005a).

On the other hand, in our data set, several lineages that are sympatric or even syntopic and show no haplotype sharing in either nuclear or mitochondrial genes have much lower divergences, such as $S$. ruber A compared to $S$. $x$ signatus. This is one of the most convincing examples demonstrating how recently diverged lineages of amphibians should be considered to be species and co-occur due to ecological differences (occurrence in savanna vs. forest; see below), and cautions once more against the uncritical use of pairwise divergences as sole indicator of species status.

\subsection{Geographical considerations}

If we interpret the six steps connecting the Guyana haplotype as variation within the same species $(S$. ruber $\mathrm{C}$, Fig. 4), the comparison with the Peru haplotype branching outside $S$. ruber A and B and connected by a minimum of 13 steps, suggests further that $S$. ruber C and S. ruber A+ B have independent biogeographical histories over South America. Additional sampling is also necessary to investigate whether $S$. boesemani might contain two sister species in French Guiana.

The restricted geographical distribution of $S$. ruber B and $S$. ruber E in central-northern French Guiana could indicate that they are lineages endemic to the region. It seems unlikely that they belong to described species of the $S$. ruber species group, which, so far, have remained undetected in French Guiana. The $S$. ruber E lineage has a small range near the towns Cayenne and Kourou, which could be seen as an indication of human introduction. However, the haplotype diversity observed in this lineage suggests a substantially long evolutionary history within French Guiana.

The comparison of the patterns among phylogroups in $S$. ruber and $R$. margaritifera reveals a rough similarity (Fig. 1), and the genetic distances between the respective lineages are identical ( 7 mutational steps, $d=\sim 1 \%$ ). The mitochondrial network pattern shown by $R$. margaritifera A is geographically sufficiently clear to suggest an evolutionary scenario. This lineage could have expanded from an ancestral range isolated in the northern part of French Guiana. This could be due to a forest refuge isolated by savannas (De Granville, 1982; Haffer, 1997) or by rising sea level (Nores, 1999) during the Quaternary. The location, in the north-east of French Guiana, of an undisturbed area that could have acted as a refugium for forest species has been suggested by De Granville (1982). Dutech et al. (2004) found some support for this hypothesis in the genetic structure of the tree Vouacapoua americana.

This hypothesis implies survival of many populations of R. margaritifera A around the northern part of French Guiana despite perturbations during the Holocene. Scattered distributions of refugial zones could increase structure by genetic drift without erasing the initial footprint generated by a Pleistocene expansion. Patterns of genetic variation are less structured in R. margaritifera $\mathrm{E}, S$. ruber A, and $S$. boesemani F. Nevertheless, they show a pattern that could be interpreted as an expansion to the east from a central origin for R. margaritifera $\mathrm{E}$ and $S$. ruber $\mathrm{A}$, and from a northwestern origin for S. boesemani $\mathrm{F}$. The patterns follow particularly the Oyapock River to the southeast.

\subsection{Hybridization in Scinax}

Two types of discordances were discovered in the molecular data set for Scinax, patterns that could be explained by past or present hybridization events.

The discordance among the nuclear and the mitochondrial genes trees for the position of $S$. x-signatus probably 
results from a past hybridization event. We assume that the mitochondrial genome of $S$. $x$-signatus has been introgressed by an ancestor of the current $S$. ruber A lineage relatively recently. After the hybridization event, lineage sorting proceeded in opposite directions for mitochondrial and nuclear molecules. Specimens of $S$. $x$-signatus sampled here retained (1) the original $S$. $x$-signatus tyrosinase haplotypes, and (2) the mitochondrial molecules originally from Scinax ruber which are today slightly differentiated from the $\mathrm{mt}$ haplotypes in $S$. ruber A (3 steps). The high nuclear distance between $S$. $x$-signatus and the $S$. ruber A, B, and C lineages in the nuclear phylogeny $(d=1.6 \%)$ is in agreement with its morphological and ecological particularities (explosive forest breeder, bigger in size and different in coloration). Mitochondrial alleles might be expected to introgress faster, on average, than nuclear loci if their persistence in a foreign gene pool is less constrained by linkage to selected loci than are the alleles of nuclear genes (Funk and Omland, 2003; Harrison, 1993). Smaller Ne of mtDNA may facilitate the fixation of an introgressed haplotype such that even low levels of introgression may be sufficient to establish a neutral mitochondrial haplotype in a foreign population (Takahata and Slatkin, 1984). The fact that $S$. $x$-signatus mitochondrial haplotypic diversity is lower than nuclear diversity (two haplotypes on mtDNA and four haplotypes on nDNA) also supports this scenario. The ranges of $S$. ruber A and $S . x$ signatus overlap at least in northwestern French Guiana around the swamps of Kaw. Here these two species are largely sympatric and genetically are reciprocally monophyletic in mitochondrial as well as nuclear markers. About their habitat, we know that $S$. ruber inhabits mainly open areas whereas $S$. $x$-signatus lives mostly in rainforests. In reproductive behavior, according to data from Guyana (Bourne, 1992) and our observations, S. ruber has an opportunistic reproductive phenology whereas $S$. x-signatus, in French Guiana, is a rather explosively breeding species. Thus, ecological factors such as habitat and reproductive phenology may prevent current hybridization.

On the other hand, our data possibly indicate ongoing or very recent hybridization between $S$. x-signatus and S. ruber C. This was inferred from the specimen $S$. $x$-signatus $\mathrm{X} 4$ that connects respectively to $S$. ruber $\mathrm{C} 1$ in the mitochondrial dataset (Fig. 4) and to S. $x$-signatus in the nuclear dataset (Fig. 5). It is particularly difficult to distinguish between incomplete lineage sorting and introgression between sister taxa. Therefore, incomplete lineage sorting for nuclear alleles is an alternative explanation of this incongruence especially since the nuclear haplotype concerned is unique.

\subsection{Hybridization and polyspecificity: two pitfalls for biodiversity estimation}

In this study, we detected several instances of polyphyletic species that require taxonomic revision. These patterns might be caused by introgressive hybridization and current hybridization or incomplete lineage sorting.
These examples illustrate a complex evolutionary history as found in studies of other taxa (e.g. Patton and Smith, 1994; Sota and Vogler, 2001). It is also another warning that the exclusive use of mitochondrial data could lead to wrong interpretations because of introgression and differential lineage sorting (Ballard and Whitlock, 2004; Meyer et al., 2006).

On the other hand, the systematics among closely related species requires dense taxonomic and geographic sampling. For example, the two already published mitochondrial sequences of $S$. ruber (from Peru and Guyana; Darst and Cannatella, 2004; Faivovich et al., 2004) correspond to two different lineages, one of which is present in French Guiana (S. ruber C) (Fig. 4). These examples illustrate a complex evolutionary history probably due to multiple and successive vicariance events in South America as also observed in other taxa (e.g. Patton and Smith, 1994; Sota and Vogler, 2001), demonstrating the importance of sampling multiple localities for related species in a combined phylogenetic/ phylogeographic approach (Funk and Omland, 2003).

As stated by Funk and Omland (2003), species level polyphyly and paraphyly are much more common phenomena than generally recognized and partially reflect the inadequacy of taxonomy to represent the underlying genetic structure of populations and species. Based on our data, it seems obvious that the number of actual species has so far been underestimated in Guianan anurans. These results also emphasize that cryptic morphological evolution of these groups is widespread and results in the discordance between morphological identification and evolutionary histories. Anuran biodiversity is more reliably estimated by an integrative approach that includes a routine molecular inventory through DNA barcoding in concert with morphological and bioacoustic techniques (Vences et al., 2005a,b). However, the isolated use of DNA sequences, without knowledge about the ecology, morphology and reproductive biology of the animals, will not allow one to reliably discern how often widespread "species" of amphibians are in fact amalgams of various reproductively isolated species.

\section{Conclusion}

This study suggests the existence of previously unknown lineages/taxa in French Guiana for the Scinax ruber species group and in the Rhinella margaritifera species group. The general lack of genetic admixture among lineages both regarding mitochondrial and nuclear genes, with only occasional evidence for introgression, together with the sympatric occurrence of many of the lineages identified, is an indication that some of the genetic lineages correspond to new species under an evolutionary species concept (Wiley, 1978) and even under a biological species concept (Mayr, 1942). The combination of simultaneous phylogeographic analysis of mitochondrial and nuclear data as employed here provides an efficient approach towards a better estimation of the biodiversity within widely distributed Neotropi- 
cal frogs. With the amphibians of the Guianas being particularly poorly known, Young et al. (2004) stated that it is clear that many more amphibian species remain to be discovered as compared to birds and mammals. Amphibian endemism of the Guianan region might be higher than previously thought and biogeographic interpretations based on species distributions and areas of endemism might need to be reassessed.

Stuart et al. (2004) asserted that the global amphibian decline is particularly worrying for Neotropical species. Given that numerous species still remain undetected, it is alarming to think that the situation could be in fact even worse than thought. If additional studies indicate polyspecificity of many existing species, conservation efforts would need to be reevaluated accordingly.

\section{Acknowledgments}

This work was supported by ECOFOR grant. We are indebted to N. Pech for statistical help and P. Gaucher (tissue loans Rhinella margaritifera and Scinax cruentommus PG 62-144), A. Amézquita (tissue loan Scinax sp. 2 from Colombia), C. Cicero (tissue loan Scinax elaeochrous MVZ 149785), M.E. Gassó i Miracle, J.W. Arntzen (tissue loan Scinax ruber RMNH 35591) and K. Elmer (tissue loans Scinax ruber QCAZ 18217-25874) for providing additional tissue samples. All the other samples have been collected in French Guiana under the permit "arreté préfectoral $n^{\circ} 186$ ID/1B/ENV 13/02/03". We also thank N. Gemmell and two anonymous reviewers for helpful comments on the manuscript.

\section{Appendix A. Supplementary data}

Supplementary data associated with this article can be found, in the online version, at doi:10.1016/j.ympev. 2006.12.006.

\section{References}

Avise, J.C., 2000. Phylogeography: The History and Formation of Species. Harvard University Press.

Ballard, J.W.O., Whitlock, M.C., 2004. The incomplete natural history of mitochondria. Mol. Ecol. 13, 729-744.

Biju, S.D., Bossuyt, F., 2003. New frog family from India reveals an ancient biogeographical link with the Seychelles. Nature 425, 711-714.

Blaustein, A.R., Wake, D.B., Sousa, W.P., 1994. Amphibian declinesjudging stability, persistence, and susceptibility of populations to local and global extinctions. Conservation Biol. 8, 60-71.

Borkin, L.Y., Litvinchuk, S.N., Rozanov, Y.M., Skorinov, D.V., 2004. On cryptic species (from the example of amphibians). Zoologichesky Zh. 83, 936-960.

Bossuyt, F., Meegaskumbura, M., Beenaerts, N., Gower, D.J., Pethiyagoda, R., Roelants, K., Mannaert, A., Wilkinson, M., Bahir, M.M., Manamendra-Arachchi, K., Ng, P.K.L., Schneider, C.J., Oommen, O.V., Milinkovitch, M.C., 2004. Local endemism within the western Ghats - Sri Lanka biodiversity hotspot. Science 306, 479-481.

Bossuyt, F., Milinkovitch, M.C., 2000. Convergent adaptive radiations in Madagascan and Asian ranid frogs reveal covariation between larval and adult traits. Proc. Natl. Acad. Sci. USA 97, 6585-6590.
Boujard, T., Pascal, M., Meunier, J.F., Le Bail, P.Y., 1997. Poissons de Guyane. Guide ecologique de l'Approuague et de la réserve des Nouragues. INRA.

Bourne, G.R., 1992. Lekking behavior in the Neotropical frog Ololygon rubra. Behav. Ecol. Sociobiol. 31, 173-180.

Bourne, G.R., York, H., 2001. Vocal behaviors are related to nonrandom structure of anuran breeding assemblages in Guyana. Ethol. Ecol. Evol. $13,313-329$.

Caron, H., Dumas, S., Marque, G., Messier, C., Bandou, E., Petit, R.J., Kremer, A., 2000. Spatial and temporal distribution of chloroplast DNA polymorphism in a tropical tree species. Mol. Ecol. 9, 1089-1098.

Castresana, J., 2000. Selection of conserved blocks from multiple alignments for their use in phylogenetic analysis. Mol. Biol. Evol. 17, 540552.

Charles-Dominique, P., Blanc, P., Larpin, D., Ledru, M.P., Riera, B., Sarthou, C., Servant, M., Tardy, C., 1998. Forest perturbations and biodiversity during the last ten thousand years in French Guiana. Acta Oecol. Int. J. Ecol. 19, 295-302.

Chek, A.A., Austin, J.D., Lougheed, S.C., 2003. Why is there a tropicaltemperate disparity in the genetic diversity and taxonomy of species? Evol. Ecol. Res. 5, 69-77.

Chek, A.A., Lougheed, S.C., Bogart, J.P., Boag, P.T., 2001. Perception and history: molecular phylogeny of a diverse group of neotropical frogs, the 30chromosome Hyla Anura: Hylidae. Mol. Phylogenet. Evol. 18, 370-385.

Cherry, L.M., Case, S.M., Wilson, A.C., 1977. Relative rates of morphological evolution in primates, carnivores and frogs. Am. Zool. 17, 910.

Chiari, Y., Vences, M., Vieites, D.R., Rabemananjara, F., Bora, P., Ravoahangimalala, O.R., Meyer, A., 2004. New evidence for parallel evolution of colour patterns in Malagasy poison frogs (Mantella). Mol. Ecol. 13, 3763-3774.

Clement, M., Posada, D., Crandall, K.A., 2000. TCS: a computer program to estimate gene genealogies. Mol. Ecol. 9, 1657-1659.

Crawford, A.J., 2003. Huge populations and old species of Costa Rican and Panamanian dirt frogs inferred from mitochondrial and nuclear gene sequences. Mol. Ecol. 12, 2525-2540.

Darst, C.R., Cannatella, D.C., 2004. Novel relationships among hyloid frogs inferred from $12 \mathrm{~S}$ and $16 \mathrm{~S}$ mitochondrial DNA sequences. Mol. Phylogenet. Evol. 31, 462-475.

De Granville, J.-J., 1988. Phytogeographical characteristics of the Guianan forests. Taxon 37, 578-594.

De Granville, J.-J., 1982. Rain forest and xeric flora refuges in french Guiana. In: Prance, G.T. (Ed.), Biological Diversification in the Tropics. Columbia Univ. Press, pp. 159-181.

De la Riva, I., Köhler, J., Lötters, S., Reichle, S., 2000. Ten years of research on Bolivian amphibians: updated checklist, distribution, taxonomic problems, literature and iconography. Rev. Esp. Herpetol., 14.

de Queiroz, K., 1998. The general lineage concept of species, species criteria, and the process of speciation. In: Howard, D.J., Berlocher, S.H. (Eds.), Endless Forms: Species and Speciation. Oxford University Press, pp. 57-75.

Duellman, W.E., 1982. Quaternary climatic - ecological fluctuations in the lowland tropics: frogs and forests. In: Prance, G.T. (Ed.), Biological Diversification in the Tropics. Columbia Univ. Press, pp. 389-402.

Duellman, W.E., 1999. Patterns of Distribution of Amphibians: A Global Perspective. Johns Hopkins University Press.

Duellman, W.E., Wiens, J.J., 1993. Hylid frogs of the genus Scinax Wagler, 1830, in Amazonian Ecuador and Peru. Museum of Natural History, the University of Kansas.

Dutech, C., Joly, H.I., Jarne, P., 2004. Gene flow, historical population dynamics and genetic diversity within French Guianan populations of a rainforest tree species, Vouacapoua americana. Heredity 92, 69-77.

Dutech, C., Maggia, L., Joly, H.I., 2000. Chloroplast diversity in Vouacapoua americana (Caesalpiniaceae), a neotropical forest tree. Mol. Ecol. 9, 1427-1432.

Dutech, C., Maggia, L., Tardy, C., Joly, H.I., Jarne, P., 2003. Tracking a genetic signal of extinction-recolonization events in a neotropical tree species: Vouacapoua americana Aublet in French Guiana. Evolution $57,2753-2764$. 
Efron, B., 1979. 1977 Rietz Lecture - bootstrap methods-another look at the jackknife. Ann. Stat. 7, 1-26.

Faivovich, J., García, P.C.A., Ananias, F., Lanari, L., Basso, N.G., Wheeler, W.C., 2004. A molecular perspective on the phylogeny of the Hyla pulchella species group (Anura, Hylidae). Mol. Phylogenet. Evol. 32, 938950.

Faivovich, J., Haddad, C.F.B., García, P.C.A., Frost, D.R., Campbell, J.A., Wheeler, W.C., 2005. Systematic review of the frog family hylidae, with special reference to Hylinae: phylogenetic analysis and taxonomic revision. Bull. Am. Museum Nat. Hist. 294, 1-240.

Farris, J.S., Kallersjo, M., Kluge, A.G., Bult, C., 1994. Testing Significance of Incongruence. Cladistics-The International Journal of the Willi Hennig Society 10, 315-319.

Felsenstein, J., 1985. Confidence limits on phylogenies — an approach using the bootstrap. Evolution 39, 783-791.

Frailey, C.D., Lavina, E.L., Rancy, A., Filho, J.P.S., 1989. A proposed Pleistocene/Holocene lake in the Amazona basin and its significance to Amazonian geology and biogeography. Acta Amazonica 18, 119-143.

Frost, D.R., 2004. Amphibian Species of the World: an Online Reference. Version 3.0. New York: American Museum of Natural History. [Electronic Database accessible at <http://research.amnh.org/herpetology/ amphibia/index.html/>].

Frost, D.R., Hillis, D.M., 1990. Species in concept and practice-herpetological applications. Herpetologica 46, 87-104.

Frost, D.R., Grant, T., Faivovich, J., Bain, R.H., Haas, A., Haddad, C.F.B., De Sa, R.O., Channing, A., Wilkinson, M., Donnellan, S.C., Raxworthy, C.J., Campbell, J.A., Blotto, B.L., Moler, P., Drewes, R.C., Nussbaum, R.A., Lynch, J.D., Green, D.M., Wheeler, W.C., 2006. The Amphibian tree of life. Bull. Am. Museum Nat. Hist. 297, 1-370.

Funk, D.J., Omland, K.E., 2003. Species-level paraphyly and polyphyly: frequency, causes, and consequences, with insights from animal mitochondrial DNA. Ann. Rev. Ecol. Evol. Syst. 34, 397-423.

Garcia-Paris, M., Alcobendas, M., Buclkey, D., Wake, D.B., 2003. Dispersal of viviparity across contact zones in Iberian populations of fire salamanders (Salamandra) inferred from discordance of genetic and morphological traits. Evolution 57, 129-143.

Gaston, K.J., Williams, P.H., 1996. Spatial patterns in taxonomic diversity. In: Gaston, K.J. (Ed.), Biodiversity: A Biology of Numbers and Difference. Blackwell Science, pp. 202-229.

Glaw, F., Köhler, J., 1998. Amphibian species diversity exceeds that of mammals. Herpetol. Rev. 29, 11-12.

Goldstein, P., Wyner, K., Doukakis, P., Egan, M.G., Amato, G., Rosenbaum, H., DeSalle, R., 2005. Theory and methods for diagnosing species and populations in conservation. Ann. Mo. Bot. Garden 92, $12-27$.

Goldstein, P.Z., DeSalle, R., Amato, G., Vogler, A.P., 2000. Conservation genetics at the species boundary. Conservation Biol. 14, 120-131.

Gorzula, S., Señaris, C., 1998. Contribution to the herpetofauna of the Venezuelan Guayana I.A data base. xviii+270+32pp.

Grant, T., Frost, D.R., Caldwell, J.P., Gagliardo, R., Haddad, C.F.B., Kok, P.J.R., Means, D.B., Noonan, B.P., Schargel, W.E., Wheeler, W.C., 2006. Phylogenetic systematics of dart-poison frogs and their relatives (Amphibia: Athesphatanura: Dendrobatidae). Bull. Am. Museum Nat. Hist. 299, 1-262.

Grant, T., Kluge, A.G., 2003. Data exploration in phylogenetic inference: scientific, heuristic, or neither. Cladistics 19, 379-418.

Graybeal, A., 1997. Phylogenetic relationships of bufonid frogs and tests of alternate macroevolutionary hypotheses characterizing their radiation. Zool. J. Linnean Soc. 119, 297-338.

Haffer, J., 1969. Speciation in amazonian forest birds. Science 165, $131-$ 137.

Haffer, J., 1990. Geoscientific aspects of allopatric speciation. In: Peters, G., Hutterer, R. (Eds.), Vertebrates in the Tropics, Museum A. Koenig, pp. $45-60$.

Haffer, J., 1997. Alternative models of vertebrate speciation in Amazonia: an overview. Biodiversity Conservation 6, 451-476.

Hanken, J., 1999. Why are there so many new amphibian species when amphibians are declining? Trends Ecol. Evol. 14, 7-8.
Harrison, R.G., 1993. Hybrid Zones and the Evolutionary Process. Oxford University Press.

Hass, C.A., Dunski, J.F., Maxson, L.R., Hoogmoed, M.S., 1995. Divergent lineages within the Bufo margaritifer complex (Amphibia, Anura, Bufonidae) revealed by albumin immunology. Biotropica 27, 238-249.

Haas, W., 2004. Beitrag zur Biologie und Verbreitung dreier Vertreter des neotropischen Bufo typhonius-Komplexes (Anura: Bufonidae). Salamandra $40(3 / 4), 207-216$.

Hay, J.M., Ruvinsky, I., Hedges, S.B., Maxson, L.R., 1995. Phylogenetic relationships of amphibian families inferred from DNA sequences of mitochondrial 12s and 16s ribosomal RNA genes. Mol. Biol. Evol. 12, 928-937.

Hoegg, S., Brinkmann, H., Taylor, J.S., Meyer, A., 2004. Phylogenetic timing of the fish-specific genome duplication correlates with the diversification of teleost fish. J. Mol. Evol. 59, 190-203.

Hoogmoed, M.S., 1979. The herpetofauna of the Guianan region. In: Duellman, W.E. (Ed.), The South American Herpetofauna: Its Origin, Evolution and Dispersal., Museum of Natural History, University of Kansas, pp. 241-279.

Hoogmoed, M.S., 1990. Biosystematics of South American Bufonidae, with special reference to the Bufo "typhonius group. In: Peters, G., Hutterer, R. (Eds.), Vertebrates in the tropics, Museum Alexander Koenig, pp. 113-123.

Houlahan, J.E., Findlay, C.S., Schmidt, B.R., Meyer, A.H., Kuzmin, S.L., 2000. Quantitative evidence for global amphibian population declines. Nature 404, 752-755.

Jarman, S.N., Elliott, N.G., 2000. DNA evidence for morphological and cryptic Cenozoic speciations in the Anaspididae, 'living fossils' from the Triassic. J. Evol. Biol. 13, 624-633.

Jegu, M., Keith, P., 1999. Lower Oyapock River as northern limit for the Western Amazon fish fauna or only a stage in its northward progression. C. R. Acad. Sci. III 322, 1133-1143.

Joyce, D.A., Lunt, D.H., Bills, R., Turner, G.F., Katongo, C., Duftner, N., Sturmbauer, C., Seehausen, O., 2005. An extant cichlid fish radiation emerged in an extinct Pleistocene lake. Nature 435 (7038), 90-95.

Köhler, J., Vieites, D.R., Bonett, R.M., Garcia, F.H., Glaw, F., Steinke, D., Vences, M., 2005. New amphibians and global conservation: a boost in species discoveries in a highly endangered vertebrate group. Bioscience $55,693-696$

Kuchta, S.R., Tan, A.M., 2005. Isolation by distance and post-glacial range expansion in the rough-skinned newt, Taricha granulosa. Mol. Ecol. 14, 225-244.

Kumar, S., Tamura, K., Jakobsen, I.B., Nei, M., 2001. MEGA2: Molecular Evolutionary Genetics Analysis Software. Bioinformatics 17, 1244 1245.

Ledru, M.P., Blanc, P., Charles-Dominique, P., Fournier, M., Martin, L., Riera, B., Tardy, C., 1997. Palynological reconstruction of the rain forest in French Guiana during the past 3000 years. C. R. Acad. Sci. II Fascicule a-Sciences De La Terre Et Des Planetes 324, 469-476.

Lescure, J., Marty, C., 2000. Atlas des Amphibiens de Guyane. Muséum national d'Histoire naturelle

Lougheed, S.C., Gascon, C., Jones, D.A., Bogart, J.P., Boag, P.T., 1999. Ridges and rivers: a test of competing hypotheses of Amazonian diversification using a dart-poison frog (Epipedobates femoralis). Proc. $\mathrm{R}$. Soc. Lond. B 266, 1829-1835.

Maxson, L.R., 1984. Molecular probes of phylogeny and biogeography in toads of the widespread genus Bufo. Mol. Biol. Evol. 1, 345-356.

Mayr, E., 1942. Systematics and the Origin of Species. Columbia University Press, New York.

Meegaskumbura, M., Bossuyt, F., Pethiyagoda, R., Manamendra-Arachchi, K., Bahir, M., Milinkovitch, M.C., Schneider, C.J., 2002. Sri Lanka: an amphibian hot spot. Science 298, 379.

Meyer, A., Salzburger, W., Schartl, M., 2006. Hybrid origin of a swordtail species (Teleostei: Xiphophorus clemenciae) driven by sexual selection. Mol. Ecol. 15 (3), 721.

Meyer, C.P., Paulay, G., 2005. DNA barcoding: Error rates based on comprehensive sampling. PLoS Biol. 3 (12), 1-10. 
Miquelis, A., Martin, J.-F., Carson, E.W., Brun, G., Gilles, A., 2000. Performance of 18S rDNA helix E23 for phylogenetic relationships within and between the Rotifera-Acanthocephala clades. C. R. Acad. Sci. III 323, 925-941.

Monsen, K.J., Blouin, M.S., 2003. Genetic structure in a montane ranid frog: restricted gene flow and nuclear-mitochondrial discordance. Mol. Ecol. 12, 3275-3286.

Moritz, C., 1994a. Applications of mitochondrial DNA analysis in conservation-a critical-review. Mol. Ecol. 3, 401-411.

Moritz, C., 1994b. Defining evolutionarily significant units for conservation. Trends Ecol. Evol. 9, 373-375.

Moritz, C., Schneider, C.J., Wake, D.B., 1992. Evolutionary relationships within the Ensatina eschscholtzii complex confirm the ring species interpretation. Syst. Biol. 41, 273-291.

Myers, N., Mittermeier, R.A., Mittermeier, C.G., Da Fonseca, G.A.B., Kent, J., 2000. Biodiversity hotspots for conservation priorities. Nature 403, 853-858.

Noonan, B.P., Gaucher, P., 2005. Phylogeography and demography of Guianan harlequin toads (Atelopus): diversification within a refuge. Mol. Ecol. 14, 3017-3031.

Nores, M., 1999. An alternative hypothesis for the origin of Amazonian bird diversity. J. Biogeogr. 26, 475-485.

Patton, J.L., Smith, M.F., 1994. Paraphyly, polyphyly, and the nature of species boundaries in pocket gophers (genus Thomomys). Syst. Biol. 43, $11-26$.

Posada, D., Crandall, K.A., 1998. MODELTEST: testing the model of DNA substitution. Bioinformatics 14, 817-818.

Pramuk, J.B., 2006. Phylogeny of South American Bufo (Anura: Bufonidae) inferred from combined evidence. Zool. J. Linnean Soc. 146, 407452.

Räsänen, M.E., Salo, J.S., Jungner, H., 1991. Holocene floodplain lake sediments in the Amazon-C-14 dating and paleoecological use. Quat. Sci. Rev. 10,363-372.

Räsänen, M.E., Salo, J.S., Jungner, H., Pittman, L.R., 1990. Evolution of the western Amazon lowland relief: impact of andean foreland dynamics. Terra Nova 2, 320-332.

Richards, C.M., Moore, W.S., 1996. A phylogeny for the African treefrog family Hyperoliidae based on mitochondrial rDNA. Mol. Phylogenet. Evol. 5, 522-532.

Ronquist, F., Huelsenbeck, J.P., 2003. MrBayes 3: Bayesian phylogenetic inference under mixed models. Bioinformatics 19, 1572-1574.

Ruvinsky, I., Maxson, L.R., 1996. Phylogenetic relationships among bufonoid frogs (Anura: Neobatrachia) inferred from mitochondrial DNA sequences. Mol. Phylogenet. Evol. 5, 533-547.

Salducci, M.-D., Marty, C., Chappaz, R., Gilles, A., 2002. Molecular phylogeny of French Guiana Hylinae: implications for the systematic and biodiversity of the neotropical frogs. C. R. Biol. 325, 141-153.

Salducci, M.-D., Marty, C., Fouquet, A., Gilles, A., 2005. Phylogenetic relationships and biodiversity in Hylids (Anura: Hylidae) from French Guiana. C. R. Biol. 328, 1009-1024.

Salzburger, W., Meyer, A., 2004. The species flocks of East African cichlid fishes: recent advances in molecular phylogenetics and population genetics. Naturwissenschaften 91, 277-290.

Sequeira, F., Alexandrino, J., Rocha, S., Arntzen, J.W., Ferrand, N., 2005. Genetic exchange across a hybrid zone within the Iberian endemic golden-striped salamander, Chioglossa lusitanica. Mol. Ecol. 14, 245-254.

Shimodaira, H., Hasegawa, M., 1999. Multiple comparison of log-likelihoods with applications to phylogenetic inference. Mol. Biol. Evol. 16, $1114-1116$.

Sites, J.W., Marshall, J.C., 2003. Delimiting species: a Renaissance issue in systematic biology. Trends Ecol. Evol. 18, 462-470.

Sites, J.W., Marshall, J.C., 2004. Operational criteria for delimiting species. Ann. Rev. Ecol. Evol. Syst. 35, 199-227.
Sota, T., Vogler, A.P., 2001. Incongruence of mitochondrial and nuclear gene trees in the carabid beetles Ohomopterus. Syst. Biol. 50, 39-59.

Steiner, C., Catzeflis, F.M., 2003. Mitochondrial diversity and morphological variation of Marmosa murina (Didelphidae) in French Guiana. J. Mammal. 84, 822-831.

Stuart, B.L., Inger, R.F., Voris, H.K., 2006. High level of cryptic species diversity revealed by sympatric lineages of Southeast Asian forest frogs. Biol. Lett. 2, 470-474.

Stuart, S.N., Chanson, J.S., Cox, N.A., Young, B.E., Rodrigues, A.S.L., Fischman, D.L., Waller, R.W., 2004. Status and trends of amphibian declines and extinctions worldwide. Science 306, 1783-1786.

Swofford, D.L., 2002. PAUP*: Phylogenetic Analysis Using Parsimony (*and Other Methods), version 4.0b10 [computer program]. Sunderland (Massachusetts): Sinauer.

Takahata, N., Slatkin, M., 1984. Mitochondrial gene flow. Proc. Natl. Acad. Sci. USA 81, 1764-1767.

Thompson, J.D., Gibson, T.J., Plewniak, F., Jeanmougin, F., Higgins, D.G., 1997. The ClustalX windows interface: flexible strategies for multiple sequence alignment aided by quality analysis tools. Nucleic Acids Res. 24, 4876-4882.

Van de Peer, Y., Caers, A., De Rijk, P., De Wachter, R., 1998. Database on the structure of small ribosomal subunit RNA. Nucleic Acids Res. 26, 179-182.

Van Vuuren, B.J., Kinet, S., Chopelet, J., Catzeflis, F., 2004. Geographic patterns of genetic variation in four Neotropical rodents: conservation implications for small game mammals in French Guiana. Biol. J. Linnean Soc. 81, 203-218.

Vélez-Rodríguez, C.M., 2004. Sistemática de los sapos neotropicales pertenecientes al grupo Bufo typhonius (Bufonidae). Tesis Doctoral. Universidad austral de Chile. Valdivia Chile. 159 pp.

Vences, M., Kosuch, J., Boistel, R., Haddad, C.F.B., La Marca, E., Lötters, S., Veith, M., 2003. Convergent evolution of aposematic coloration in Neotropical poison frogs: a molecular phylogenetic perspective. Organ. Divers. Evol. 3, 215-226.

Vences, M., Kosuch, J., Lötters, S., Widmer, A., Jungfer, K.H., Köhler, J., Veith, M., 2000. Phylogeny and classification of poison frogs (Amphibia: Dendrobatidae), based on mitochondrial 16S and $12 \mathrm{~S}$ ribosomal RNA gene sequences. Mol. Phylogenet. Evol. 15, 34-40.

Vences, M., Thomas, M., Bonett, R.M., Vieites, D.R., 2005a. Deciphering amphibian diversity through DNA barcoding: chances and challenges. Philos. Trans. R. Soc. Lond. B 360, 1859-1868.

Vences, M., Thomas, M., Van der Meijden, A.Y., Chiari, Y., Vieites, D.R., 2005b. Comparative performance of the 16S rRNA gene in DNA barcoding of amphibians. Frontiers Zool. 2.

Wake, D.B., Jockusch, E.L., 2000. Detecting species borders using diverse data sets. In: Bruce, R.C., Jaeger, R.G., Houck, L.D. (Eds.), The Biology of Plethodontid Salamanders. Kluwer Academic/Plenum Publishers, pp. 95-119.

Wiley, E.O., 1978. Evolutionary species concept reconsidered. Syst. Zool 27, 17-26.

Wilson, E.O., 1992. The Diversity of Life. Belknap Press of Harvard University Press.

Wynn, A., Heyer, W.R., 2001. Do geographically widespread species of tropical amphibians exist? An estimate of genetic relatedness within the neotropical frog Leptodactylus fuscus (Schneider 1799) (Anura Leptodactylidae). Trop. Zool. 14, 255-285.

Young, B.E., Stuart, S.N., Chanson, J.S., Cox, N.A., Boucher, T.M., 2004. Disappearing Jewels: The Status of NewWorld Amphibians. NatureServe.

Zangari, F., Cimmaruta, R., Nascetti, G., 2006. Genetic relationships of the western Mediterranean painted frogs based on allozymes and mitochondrial markers: evolutionary and taxonomic inferences (Amphibia, Anura, Discoglossidae). Biol. J. Linnean Soc. 87, 515-536. 